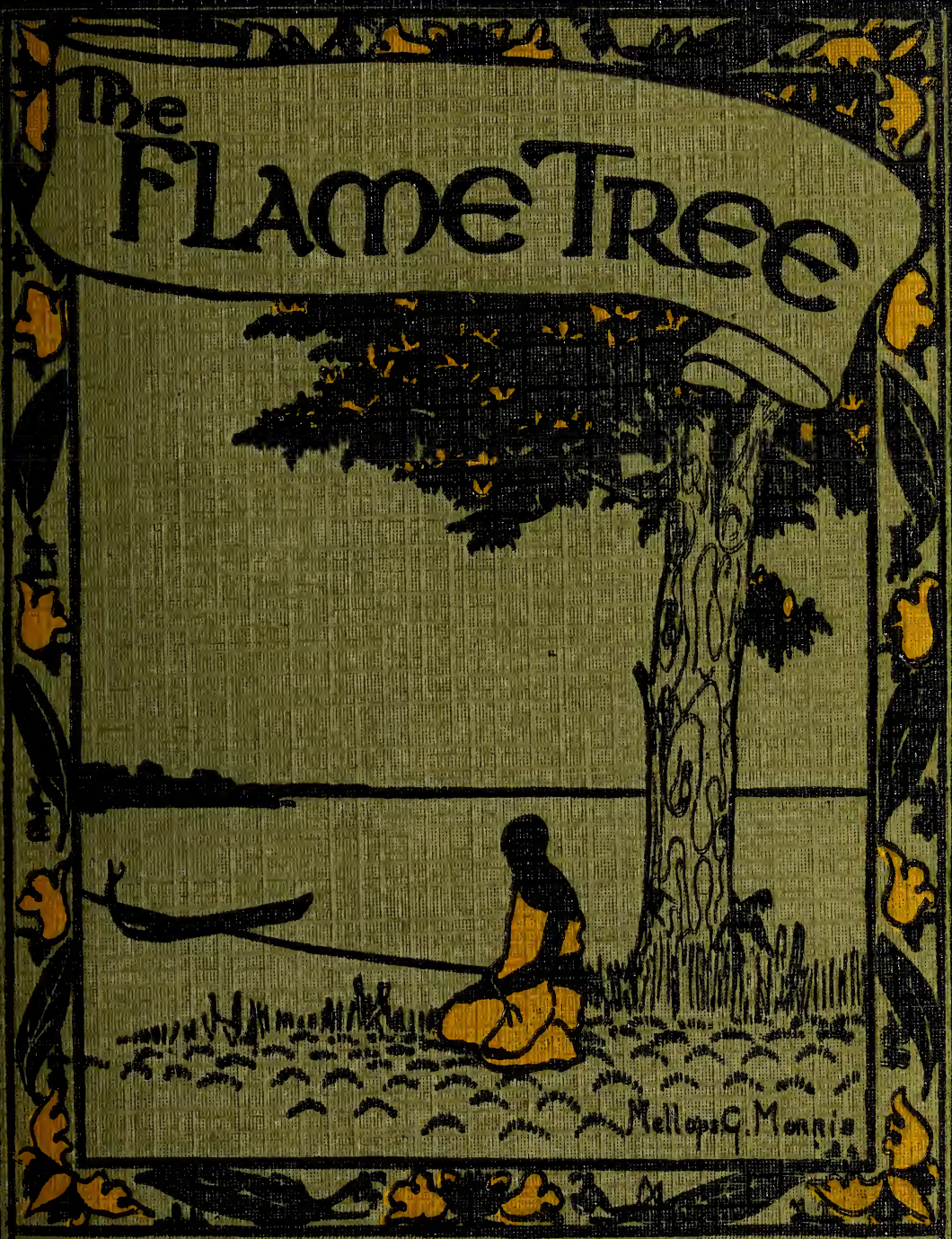

Rosetta Baskerville 





\section{THE FLAME TREE}


BY THE SAME AUTHOR. THE KING OF THE SNAKES, and other Folk-Lore Stories from Uganda. With Illustrations. Paper cover, Is. Cloth boards, 2s. net.

THE SHELDON PRESS 
AND OTHER FOLK-LORE STORIES FROM UGANDA

BY

MRS. GEORGE BASKERVILLE

WITH ILLUSTRATIONS BY MRS. E. G. MORRIS

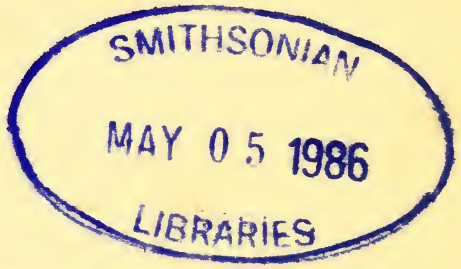

LÓNDON

THE SHELDON PRESS NORTHUMBERLAND AVENUE, W.C.2 NEW YORK AND TORONTO: THE MACMILLAN CO. KAMPALA : THE UGANDA BOOKSHOP PRINTED IN GREAT BRITAIN 
TO

MY CHARMING

NEPHEWS AND NIECES 


\section{PREFACE}

I AM again indebted to Sir Apolo Kagwa, K.C.M.G., M.B.E., for some of the stories from his "Engero za Baganda." It is impossible to acknowledge by name all my Baganda friends to whom I owe the rest-but each story recalls to my memory a vivid Uganda scene-a shady banana garden, a smoky kitchen, the bedside of a sick woman in a stuffy hut, or a camp fire beneath a star-spangled sky-all gentle soft-voiced people who allowed me to share their lives for a little while, and tried in their simple way to be kind to me. My thanks are due to Miss Muriel Robertson, for allowing me to use her Uganda songs, and to the Westminster Gazette for permission to reprint them.

ROSETTA BASKERVILLE. 



\section{CONTENTS}

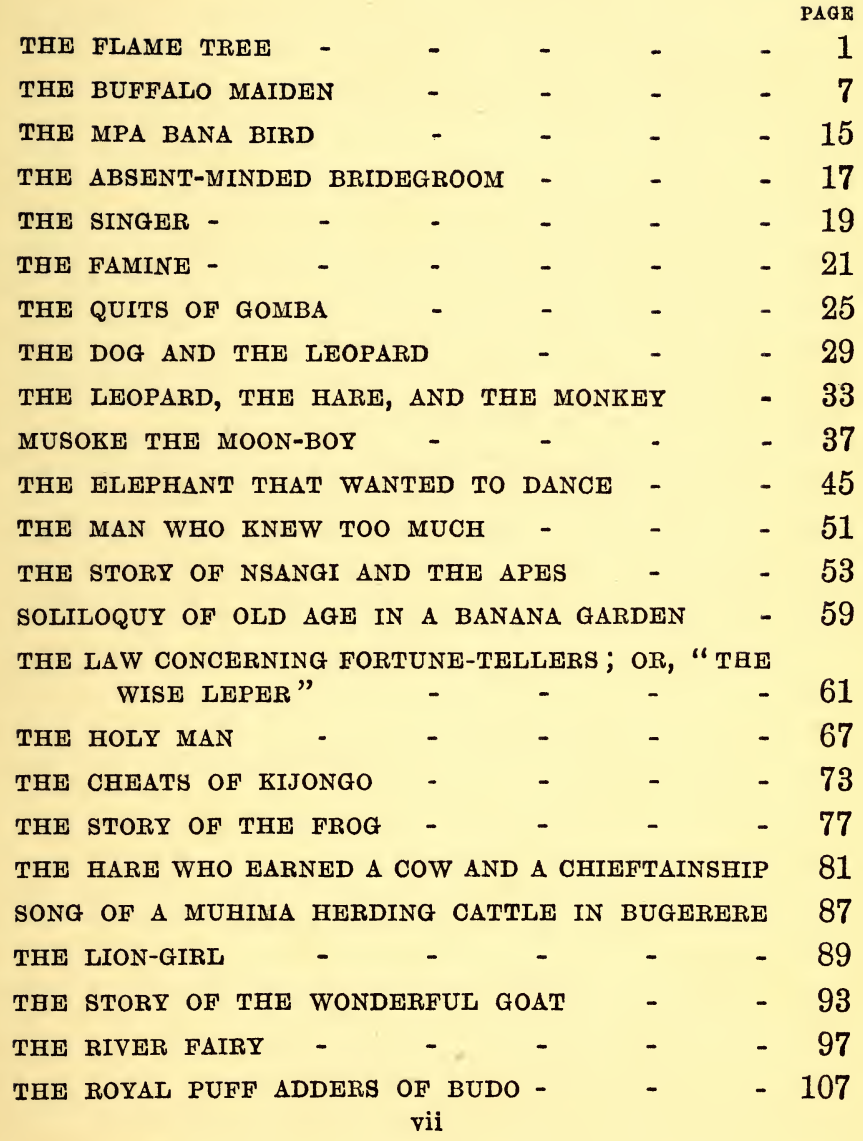




\section{LIST OF ILLUSTRATIONS}

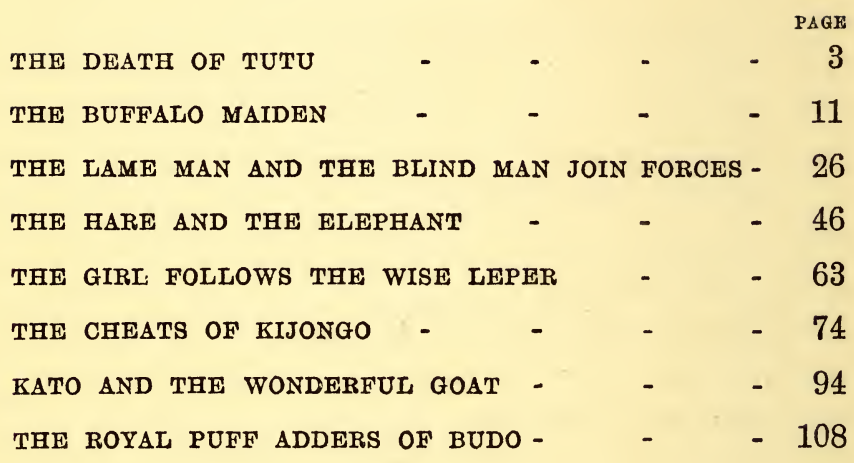




\section{THE FLAME TREE}

ONCE upon a time there was a little girl who lived in the village of $\mathrm{Si}$. Her parents had no other children, and as she grew older they saw with joy that she was more beautiful every day. People who passed through the village saw her and spoke of her beauty until every one in Kyagwe knew that the most lovely girl in the country lived in the village of Si-and every one in the province called her " the Maiden." The Maiden was a gentle, sweet child, and she loved all the animals and birds and butterflies and flowers, and played with them and knew their language. Her parents were very proud of her, and often talked of the time when she should be grown up and marry a great chief with many cows and gardens and people, and bring great wealth to her tribe. When the time came to arrange her marriage, all the Chiefs came and offered many gifts, as the custom of the Baganda is ; but the Maiden said, "I will marry none of these rich Chiefs, I will marry Tutu the peasant boy, who has nothing, because I love him." Her parents were very grieved when they heard this, and would have tried to persuade her, but just then a messenger arrived from the Sekibobo 
to say that the King of Uganda was going to war with Mbubi the chief of the Buvuma Islands, and all the chiefs went away to collect their people for the King's army. Then the Chief of Si, who is called Kibevu, called all his men together, and Tutu the peasant boy went with them. The army marched down to the Lake shore to fight the Islanders who came across the blue waters in a fleet of war canoes, painted and decorated with horns and feathers and cowry shells and beads. The Maiden was very sad when she said good-bye to Tutu. "Be very brave and win glory," she said, " then my father will let me marry you, for I will never marry any one else." But when the men had marched away and only the women and children were left in the village with the old people, the Maiden forgot her brave words and only thought how she could bring Tutu safely back.

She called to her friend the hawk. "Come and help me, Double-Eye; fly quickly to the Lake shore and see my peasant boy-tell him I think of him day and night. I cannot be happy till he returns." The hawk knew Tutu well, for often on the hillside he had played with the children. The Baganda called him "DoubleEye," for they say, that, with one eye he watches the Earth and with the other he sees where he is going.

The Baganda reached the Lake, and there was a great battle, and Tutu the peasant boy was killed by a stone from an Islander's sling; but the Baganda rallied, and drove the enemy 
back to their canoes, and Mbubi beat the retreat drum, and his men returned to Buvuma. The hawk flies very quickly, and while he was still a long way off he saw Tutu lying where he had fallen on the Lake shore. The soldiers were

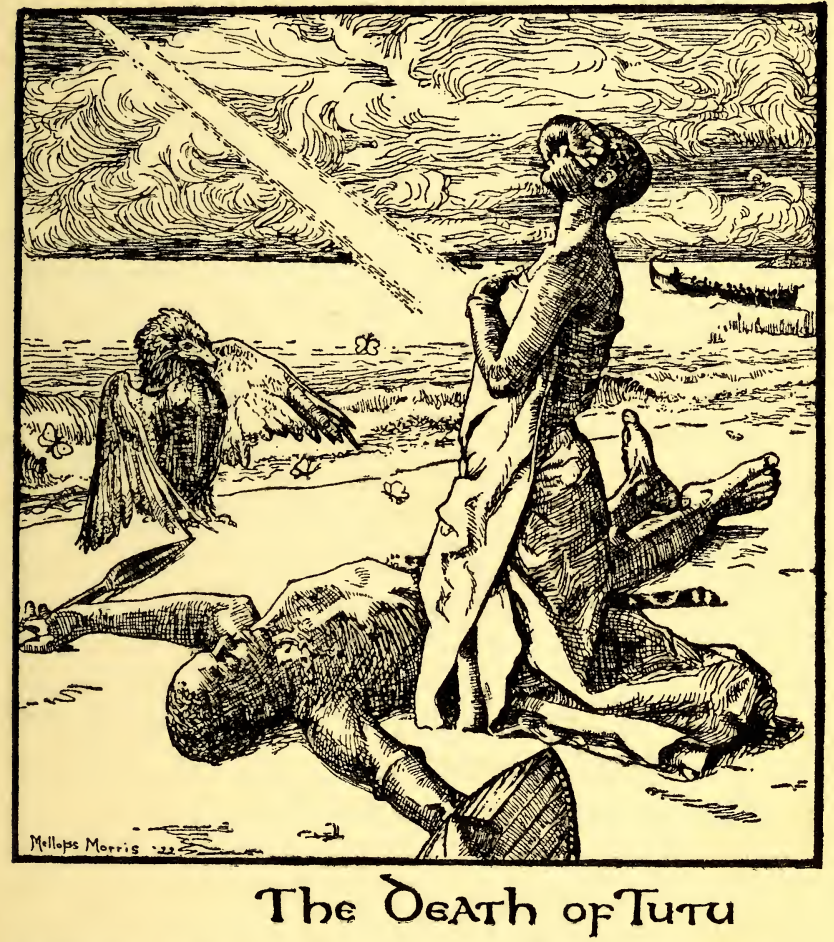

burying the dead, and the hawk watched to see where they would bury the peasant boy of $\mathrm{Si}$, that he might show the maiden his grave. The Maiden waited on the hillside for the 
hawk's return and the moments seemed like hours. She called to a bumble bee who was her friend. "Go quickly to the Lake side and greet my peasant boy, tell him I wait here on the hillside for his return."

The bumble bee flew away quickly, and when he reached the Lake shore he asked the hawk for news. "The Islanders have fled in their canoes, but Tutu the peasant boy is dead, a stone from a sling killed him. I wait to see his grave that I may show it to the Maiden." The bumble bee was afraid to go back with the news, so he stayed near the hawk and watched. Meunwhile the Maiden waited in a fever of impatience, ever gazing at the distant Lake and pacing up and down. She saw a flight of white butterflies playing hide-and-seek round a mimosa bush and called to them.

" Oh, white butterflies, how can you play when my heart is breaking? Go to the Lake shore and see if my peasant boy is well."

So the white butterflies flew away over the green hills to the Lake and arrived on the battlefield just as the soldiers were digging Tutu's grave, and they settled sadly down on a tuft of grass, their wings drooping with sorrow, for they loved the Maiden who had often played with them in the sunshine. Far away on the Si hills the Maiden watched in vain for their return. Filled with fear she cried to the Sun, " Oh, Chief of the Cloud Land, help me! take me on one of your beams to the Lake shore that I may see my peasant boy and tell him of my 
love." The Sun looked down on her with great pity, for he had seen the battle and knew that Tutu the peasant boy was dead. He stretched out one of his long beams and she caught it in her hands, and he swung her gently round until she rested on the Lake shore. When she saw the soldiers lifting Tutu's body to lay it in the grave she cried to the Sun :

"Oh, Chief of the Cloud Land, do not leave me, burn me with your fire, for how can I live, now that my Love is dead?" Then the Sun was filled with pity and struck her with a hot flame, and the soldiers were very sorry for her too, and they dug a grave for her next to Tutu's.

And when the people of $\mathrm{Si}$ visited the graves the next year they found a wonderful thing, for a beautiful tree had grown out of them with large flame-coloured blossoms which ever turned upwards to the sun, and they took the seeds and planted them in their gardens. And now the country is full of these beautiful trees which are called Flame Trees, but the old people call them Kifabakazi, because the stem is as soft as a woman's heart and a woman can cut it down. 



\section{THE BUFFALO MAIDEN}

There was once a little girl who lived with her uncle and aunt. Her uncle loved her, but the aunt was always unkind to her. Now, this aunt was really a witch, but no one knew it. One day she said to her husband: "You must send that little girl away, I cannot stand her any more, she is so naughty, but go first to the forest to the old wizard who lives there and he will tell you what to do."

So the man went to the forest, but he did not know that his wife had told the wizard what to say. The wizard said: "Take the little girl to the forest and leave her there."

Then he was sorry for the man, and added : "If you do this, good fortune will come to the child, but many years must pass." Very sadly the man returned home. He took a gourd of milk and some Indian corn and told his little niece to follow him into the forest. When they had walked a long way they sat down to rest, and the child was so tired that she fell asleep at once. Then the uncle put down the gourd of milk and the Indian corn and went sorrowfully home. When the child woke it was very dark 
in the forest, and she was terrified at the sounds round her and feared the wild animals might come and eat her; but she heard a chirping voice in the tree above her, and saw a large cricket sitting on a branch just over her head: "Climb up into this tree," said the cricket, "and you will find a nice bed to sleep in."

So the child climbed up into the fork of the tree, and there was a lovely place full of dry leaves, where she cuddled down and was soon fast asleep again. The next morning she saw that several buffaloes were resting under her tree, and as she was very hungry she thought: "I will go and ask the cow buffalo to give me some milk."

The buffaloes were very sorry for the child left all alone in the Forest, and they said :

"You will soon die of hunger here-come and live in our kraal in the jungle, and you shall have milk every day and a little hut all of your own."

So the little girl climbed on the old cow buffalo's back, who was the Granny in the herd, and went with her to the kraal which was hidden away in the thick jungle. At first she was sad and unhappy and homesick. She wanted her uncle, and her friends in the village at home, and the old granny buffalo could do nothing to comfort her.

Then the great bull buffalo who ruled the herd called a council of animals together and said : "How can we make this child happy who has come to live with us in the Forest? 
The animals were much distressed; for they all wanted to be kind. But the child sat and sobbed, for she was lonely and homesick. Just then an old tortoise who had been asleep for many years, woke up, and came shuffling into the Council. "The child will be quite happy if you take away her heart," he said. "For it is the heart of a woman that brings all the trouble into the world, if she cannot love she will give no trouble, if she has no heart she will be quite happy." So they cut out the little girl's heart and tied it up in wild plantain leaves and hung it up in a cedar tree, and they built her a hut under the cedar tree, and she settled down happily and cried no more, and her heart hung far above out of reach where no one could touch it.

From that moment the child changed, at first the buffalo granny was pleased because she stopped crying and was quiet, but soon she grew puzzled for the little girl was so strange. Every day she did unkind things and laughed when she hurt the animals. She pushed the little cubs into the Forest pools when they came to drink, and she climbed up into the trees and threw little birds that couldn't fly out of their nests, and when the mothers cried she laughed at them, and clapped her hands. There was one animal who had not been at the great bull buffalo's council. The little hare was away at the time, on a long journey, but when he returned, and the other animals told him about it, he looked very grave. The little Hare knows 
more about people than any other animal, for he often goes to the villages and he understands men's language. He watched the little girl, and every day he grew sadder. Years passed by. and the child grew up into a beautiful woman: but she had no friends in the Forest, all the animals were afraid of her, none of them loved her. If they growled she stared at them, and they slunk off, for her eyes frightened them.

One day the Sekibobo's men were hunting buffaloes, and one of them followed a wounded animal through the jungle when, to his surprise, he saw a lovely girl come down the Forest path. When she saw the wounded buffalo she laughed and went back, and the man was so frightened that he went back the way he had come, and told the other hunters, and they told the Chief. Then the Chief sent a party of men to the Forest and they followed the hunter's trail and came to the buffaloes' kraal and there they saw a beautiful girl milking a buffalo and singing:

I am the Buffalo Maiden,

The Buffalo Kraal is my home ;

The Jungle Land is my Kingdom,

Wherever I will I roam.

I hate the golden sunbeams

That fill the glades with light,

I hate the silver moonbeams

That chill my hut at night.

The birds are dumb when they see me,

The animals are my foes;

For I am the Buffalo Maiden,

As all the Jungle knows. 
They were afraid to speak, and they went quietly back.

Then the Sekibobo went to the Capital and told the Chiefs in the King's Council, and the King and all the Princes heard that a beautiful

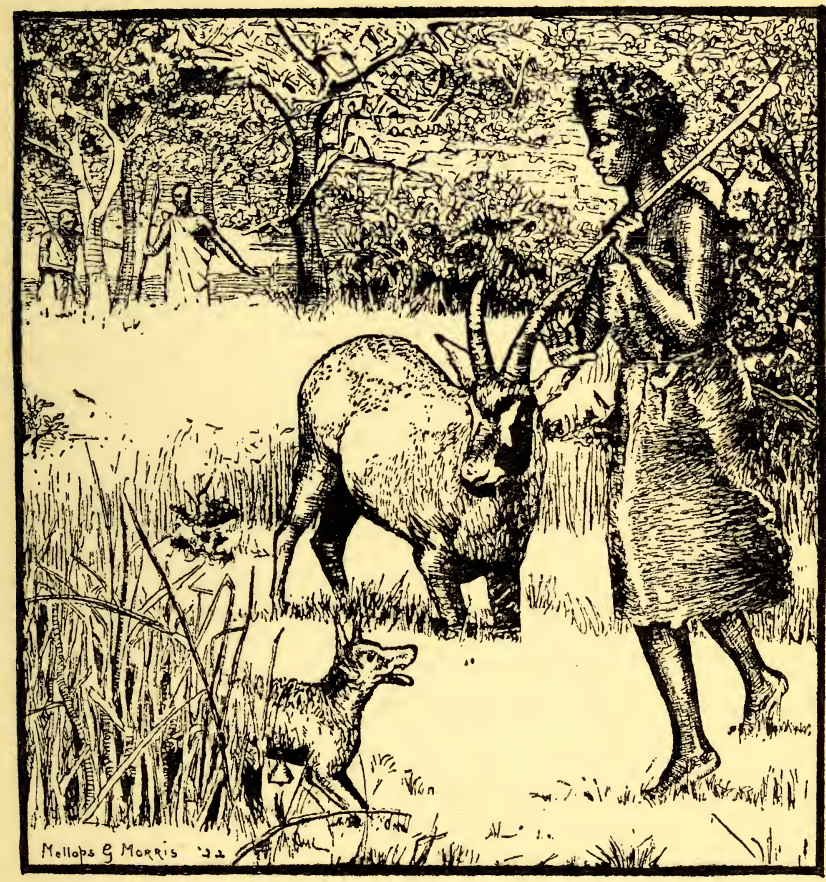

$$
\begin{aligned}
& \text { tThe-s. } \\
& \text {... Buffalo maiden }
\end{aligned}
$$

girl lived all alone in the depths of the Forest, in a buffalo kraal. There was one Prince braver and kinder than the others and he was 
sorry for the girl, so he took one man with him and went to the Forest to find her. When he found her he loved her very much, but the girl only laughed at him and threw stones at him. Some of the stones hit him, and hurt very much, and every day he grew more and more miserable. One day while he was walking in the forest he found a doe with a sharp thorn in its foot. He took the thorn out and carried the poor tired creature to its home. The doe was very grateful and said :

"Tell me what I can do to thank you."

And the Prince answered, "Tell me how I can make the girl I love love me."

The doe was very sorrowful. "You will never make her love you, she is unkind and cruel to every one, but I will ask the other animals, and perhaps they can give me advice. So when the doe's foot was healed she went to the big grey elephant and asked his advice. "Tell your Prince," said the big grey elephant, "that the girl is cruel and unkind, he had better seek a wife in the Capital." So the doe went to the lion.

"If the Prince has been kind to you, he is much too good for the girl," he said; "she is hard and cruel and never sheds tears as the women in the villages do." All the animals said the same thing, and at last the doe met the little hare and told him her trouble.

"It isn't her fault," said the hare, "they took her heart away from her when she was a little girl : how can she be kind without a heart? 
Let the Prince steal her heart that hangs in the cedar tree and then she will love him."

So the doe went and told the Prince, "You must steal her heart which hangs in the cedar tree above her hut, but you must go alone at night."

So the Prince went alone through the dark Forest at night and came to the buffaloes' kraal. The moonlight was shimmering through the grey shadows as he picked his way between the sleeping buffaloes up to the maiden's hut, and there above him in the cedar tree hung the heart. He climbed the tree and clasped the heart in his arms, and as he did so the girl asleep in the hut below felt a great fear. "Some one has touched my heart," she cried.

Softly and tremulously she opened the door and saw the Prince, and fell at his feet, sobbing "Oh, my Lord, you have my heart in your arms, take me too!" So the Prince took her away to the Capital and they lived happily together for many years.

The big grey elephant called a Forest Council together, and they passed sentence on the old tortoise and killed him, because his advice had been bad, for this is the law of the Mabira Forest - if any animal gives bad advice to the Council, he is killed. And the Forest Council sent a messenger to the Prince and told him what they had done. And he was glad; for though the heart of a woman causes all the trouble in the world it also brings all the joy, and her tears are like the spring rains and make the Earth beautiful. 



\section{THE MPA BANA BIRD}

The African cuckoo does not sing Cuckoo, Cuckoo ; it sings Cuckookoo, Cuckookoo, and it can sing this song for a whole hour, until every one in the neighbourhood is tired of hearing it, then it flies to another tree, clears its throat and begins again. The mother cuckoo is too lazy to build a nest of her own, and to hatch her own eggs. If she finds a nice comfortablelooking nest she lays an egg in it and flies away hoping the owner will hatch it for her; but she forgets so soon, that she never returns to see what has happened to her egg. One day a mother cuckoo found a lovely nest in the forest and laid an egg among the four little eggs which were in it already. Then she flew away and forgot all about it. When the owner of the nest returned, she was too tenderhearted to throw the egg out, so she hatched it with her own. But the young cuckoo was so large and hungry that he soon filled up the nest, and one day when the mother bird was away looking for food he pushed the four little fledglings out of the nest. A wild cat was passing among the bushes down below and gobbled them up 
as they fell. When the mother bird returned she found only the cuckoo in her nest, and she searched everywhere for her children crying as she went, "Mpa bana, mpa bana," which means, "Give me children, give me children." She searched under the bushes and all round her nest and then went all through the forest crying all the time, "Mpa bana, mpa bana," till all the other birds and animals knew of her sorrow. When the next nesting season came, she laid four more eggs, and never left the young birds after they were hatched, but she had got into the habit of singing this song:

I left them safe in the nest, Mpa bana, mpa bana;

Seeking the food that was best,

Mpa bana, mpa bana;

How did the cruel thief come,

Mpa bana, mpa bana;

Wrecking my joy and my home,

Mpa bana, mpa bana.

The young birds heard it all day long and learnt to sing it; and now it has become their tribal song, and they sing it for hours together, and are quite as tiresome as the cuckoo who just sings cuckookoo, cuckookoo, without grumbling about it. 


\section{THE ABSENT-MINDED BRIDEGROOM}

ONCE upon a time there was a man called Nagamba, who was very absent-minded. Everybody laughed at him, but he did not mind. $\mathrm{He}$ had many friends and was quite a good fellow. At last the time came for his marriage, and he paid the dowry and arranged the feast, and married his sweetheart, and they started on the journey to his house. But as they walked along they came to a place called Nakuse, and Nagamba remembered that a friend of his lived there; so he said to his bride :

"Sit here and rest in the shade for a little while, and I will fetch you a cooling drink."

When he got to his friend's house he found a feast going on and many people he knew were there, and he sat down with them and forgot the poor little bride sitting in the shade waiting for a cooling drink. And the sun went down, and night fell, and still he sat on and talked and joked and sang, and the dawn broke in the east and suddenly the cocks crowed. Nagamba sprang to his feet:

"My friends," he cried, "I am married, and my bride sits in the shade waiting for a cooling drink." 
They all went to find her; but the girl had become tired of waiting and had returned to her father's house, and refused to go back to Nagamba, and as no one else would marry him he remained a bachelor all his life. And now in Uganda this has become a proverb; if a man is absent-minded and forgetful, his friends say: "You will never get a wife; you will have the fate of Nagamba, the absent-minded bridegroom. 


\section{THE SINGER}

"Nyimba oluimba, oluimba lwange."

We march over hills and valleys,

Hundreds of warriors strong,

And I take my harp from my shoulder

And sing them a marching song.

I sing of a distant garden

That looks t'wards the setting sun,

In the cool green shade of the plantains

The shadows are soft and long.

I sing of a beautiful maiden,

Slim and tall, like a forest tree,

With eyes as dark as the forest pools,

And a heart that is true to me.

And when the war is over

And the warriors return to rest,

I will marry my beautiful maiden

In the garden that looks t'wards the west.

And each man marches in silence,

For each is a traveller lone, And no man asks what his neighbour thinks, For the heart of man is his own. 



\section{THE FAMINE}

A LONG time ago a terrible drought visited the countries round the Great Lake. The spring rains failed, every day the sun rose like a copper ball and made his burning way across a cloudless sky. No flowers bloomed that spring, and the grass dried upon the hillsides. The banana trees in the shady gardens looked desolate and sad, their leaves hung down limp and brown and no heavy bunches of golden fruit filled the air with sweetness. The potato patches had been baked hard and dry, and no Indian corn had been able to struggle through the hard ground. At last the people began to dig up the banana roots, and to eat the great coarse bulbs to keep themselves from starving. The lake sank lower and lower till the tall papyrus stood high above the water, and the marshy ground was seen for miles among the shallows round the shore. Great rocks stood out round the falls at Jinja, and the water trickled in small rivulets over them where every spring the waters of the Great Lake rush and tumble and roar into the river Nile. Famine and want spread over the land, but the part of the country that suffered most was Busoga. There was a large herd of elephants 
which lived in Zibondo's country, and they wandered from place to place seeking fresh grass and leaves and roots and finding nothing. At last the chief of the herd spoke.

"When I was a calf in the herd, ninety years ago, I remember a famine like this, and I remember that the Nile was so low that we found a ford and crossed into the Mabira Forest and found food there; let us go now, and seek this ford, for the waters of the river are low.

So the herd moved off towards the Nile, and as they went they passed through deserted villages and wasted country and saw the thin starving animals dragging themselves to the river. The chief of the herd led them straight to the spot he remembered, and there they saw rocky ground gleaming through shallow water and knew they had found a ford. There was one cow elephant who was walking with her calf and cheering him on.

"Courage, my child," she said, "we are nearly there. Think of the cool green glades we shall find in the Mabira Forest, for this pitiless sun can never strike through the thick creepers on the trees, and the water pools are deep and dark."

As she said this her small eyes fell on a pitiful sight. A mother monkey had carried her baby down to the river to drink, but she was too weak to lift it. The cow elephant lifted them both with her trunk and carried them across the ford into the Mabira Forest. 
The King of the Cloud Land had seen the distress on the Earth, and as he looked down on Uganda he saw what the cow elephant did. And his heart was filled with pity for the starving people and animals, and he called all his clouds together, a great army, and they poured rain on the sunbaked Earth. And where there had only been hard ground, gardens and fields sprang up, the hillsides became green with grass and brilliant with flowers, and the Great Lake rose and poured its waters over the falls, and where the shallows had been round the lake shore, the water was so deep that it reached to the feathery heads of the papyrus, and the ford across the river was lost under the tumbling rushing waters.

From that time the monkeys have always been the friends of the elephants, for though they are small they can help them. From their homes in the tree-tops they can see the hunters coming and they warn the herd. They see the hunters setting traps and they tell the elephants where they are. And this is why men prefer to hunt elephants on the plains and hillsides and fear to hunt them in the forests, for they never know whether the monkeys have seen their plans and have told the herd their secrets. 



\section{THE QUITS JF GOMBA}

THere was a battle going on round the village of Gomba.

In the village there was a lame man who had never walked. Every morning he was carried out into the sunny courtyard and every evening he was carried back to his house; but the battle was raging, and no one remembered the lame man. As he lay in his house he saw a blind man passing by, and a sudden thought struck him. He called to the blind man :

"Come here, my friend, I have something important to tell you." The blind man groped his way with his long stick till he stood before the lame man, who said:

"Listen, my friend, no one has remembered us during the battle, and assuredly we shall die, you who are blind, and I who am lame; but I have a plan: Take me on your back, and we will escape from the village. I will be eyes to you, and you shall be feet to me."

The blind man agreed to the plan and hoisted the lame man on his back, and they escaped from Gomba. When they reached safety the blind man said: " Give me a reward, for I have saved your life." 
But the lame man said, "Not so, it was I who saved yours." They spoke hot and angry words to each other, and at last they decided to take the case to the Chief's Council. But

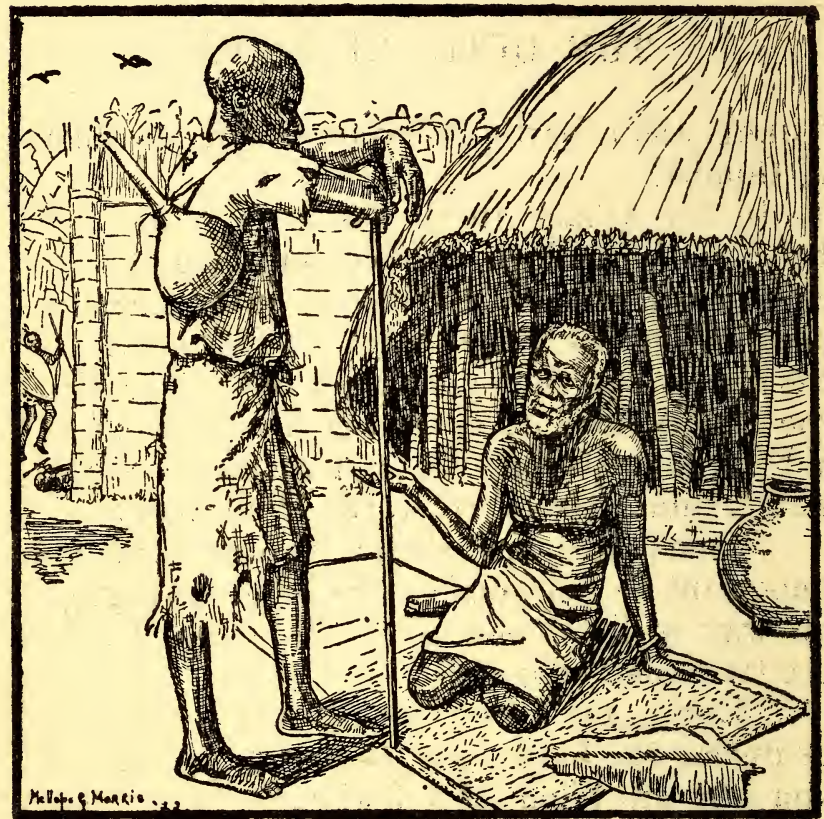

\section{The \\ - Lame man \& the Blind man * join forces?}

when the Chief heard it, he said: "There is no case; the lame man was eyes to the blind, and the blind man was feet to the lame, both have 
saved their lives, which in itself is a great reward. The words are finished."

And now this has become a proverb in Uganda. When two men quarrel and both of them are in the right (or in the wrong) the people say, "It is a case of the Quits of Gomba." 



\section{THE DOG AND THE LEOPARD}

ONCE upon a time a leopard who had several cubs hired a dog to be nurse to them, but she was very unkind to the dog, who was miserable. The dog was always thin and hungry, she only ate what was left over when the leopard and her cubs had finished a meal, and that was never much. One day when the leopard was out visiting, and the dog was left at home with the cubs, she found some bones in a corner and fell upon them ravenously. One of the cubs crept up to look, and a bone hit him in the eye and put the eye out. When the dog saw what she had done she was very frightened and ran away into the forest. She ran on until she came to the house of the old wizard, and then she thought, "I will go and have my fortune told."

So she went into the house and told the wizard what had happened. Now, the old wizard told fortunes by cards, and his cards were bits of buffalo hide, sewn over with cowry shells and beads. He got them out of his goatskin bag and was just going to tell the dog's fortune when he saw the leopard coming down the forest path, and he whispered to the dog: 
"There is the leopard coming here, climb up into that basket which hangs from the roof and lie very still."

So the dog climbed up into the basket in which the wizard kept the bananas he was ripening for beer, and lay quietly down. In a few minutes the leopard arrived, and poured out her story to the wizard. "Tell my fortune," she said, " that I may know if I shall catch my enemy." The wizard took out his cards and spoke. "You will catch your enemy in the spring rains, if she goes out in the rain you will catch her. In the sunshine she will be safe, the rain will be her downfall. I speak to those that are above, I speak to those that are below, let her who has ears hear, let her who hears understand." The leopard thanked the wizard and gave him a beautiful white hen as a present, and went away home to her cubs. When the dog came down from the basket the wizard asked :

"Did you understand my warning?" And the dog said, "I understood, sir; I will never go out in the rain."

The months passed, and one day when the dog was out in the forest a heavy shower came on. The spring rains had begun. The dog ran in the direction of home, but suddenly she saw an anthill by the road side from which the ants were beginning to fly. The dog stopped for a moment to eat a few, and then, as the succulent creatures poured out of the anthill, she lapped them up with her tongue and forgot all about the 
wizard's warning, and did not see the leopard creeping down the path. The leopard sprang upon the dog and killed her.

And from that day leopards and dogs are enemies, and a constant battle rages between the tribes, for the leopards remember how a dog blinded a cub, and the dogs remember the vengeance of the mother leopard in the spring rains. 



\section{THE LEOPARD, THE HARE, AND THE MONKEY}

ONCE upon a time a leopard and a hare lived together in one house. One day the leopard said, "Let us go to the village and steal goats." The hare did not want to steal a goat, but he wanted the leopard to go and bring some meat, so he thought of a trick, and agreed to what the leopard said. They started out in opposite directions, but the hare soon doubled back and followed the leopard who crept up the hillside towards a goat which was grazing by itself, and sprang upon it. Then the hare shouted, and the leopard, thinking the goatherds had seen him, dropped the goat and ran away.

The hare dragged the goat under some bushes, and after waiting till all was safe and quiet, took it home. The leopard was very surprised and rather sulky. When the meat was nearly cooked the hare went outside the house and shouted. The leopard thought the herdsmen had followed them, and he dashed out, and fled to the forest, and did not return till the morning, by that time the hare had eaten up all the meat-but he told the leopard that the herdsmen had come and taken it all away. This 
happened several times, till a monkey, who had watched them, told the leopard of the hare's trick, and that evening, instead of running to the forest, he only ran a little way and came back, and found the hare just sitting down to the feast. Although he was very frightened, the hare managed to slip past the leopard and jumped into an anthill which had a large hole in the top. He crouched down and was just out of reach of the leopard's paw. The ants make their home of very hard red earth, so that no storms or rain can wash it away, and the leopard knew better than to risk breaking all his claws trying to dig out the hare, so he shouted:

"Foolish creature, I will fill up the hole with fire and burn you inside it; do not think you shall escape my vengeance." He called to a crow who was sitting on a tree near by, "Come and guard my prisoner while I collect firewood."

But the crow never does anything for any one, he is too disagreeable; and besides, he did not see why the hare should be burnt in the anthill, so he answered: "I can't sit in the sun, the dust gets into my throat and makes me hoarse. I can't guard your prisoner, find some one else." Just then the monkey who had told the leopard of the hare's trick came along.

"Oh, my dear friend!" said the leopard, " come and guard the wicked hare whom you helped me to catch. I am going to burn him in the anthill."

So the monkey sat on the top of the anthill while the leopard went to collect firewood. 
THE LEOPARD, THE HARE, AND THE MONKEY 35

As the monkey sat there he heard the hare munching something. "What are you eating?" he asked.

"The white ants are swarming, and I am eating them as they come up," said the hare. "I have never eaten such beautiful ants, they are a miracle of creation."

"Give me some," said the monkey,

"Lean down into the hole," said the hare. "I bear no malice, and he who eats alone has no joy. I will give you a handful." The monkey leant down into the hole, and the hare threw a handful of dust up into his eyes. The monkey sprang back and rolled off the anthill, and the hare jumped out of the hole and ran away. The crow, sitting on a branch near by, laughed until his throat ached. The monkey wiped the dust out of his eyes and looked ruefully at the anthill.

"What shall I do when the leopard returns?" he asked the crow.

"Put colocynth seeds into the hole," said the crow, "and put some rubbish on them, and tell the leopard you have begun to build the fire for him."

So the monkey did this, and when the leopard came back with the firewood, he piled it up over the hole and they set it alight. A colocynth seed gave a loud pop!

"What is that?" said the leopard.

"One of his eyes is burnt," said the monkey solemnly.

Another seed gave a pop! "That's his 
other eye," croaked the crow. But now the seeds were all thoroughly hot, and they all began popping together, and the crow burst out laughing, and the monkey swung himself up into the tree and laughed until his sides ached, while the leopard fumed with rage, for he knew the monkey was playing some trick. He had to wait until the fire burnt out and the smoke blew away before he could look down into the hole, and then he saw only ashes and twigs and knew that the hare had escaped.

And from that day leopards have hated monkeys, and kill them if they meet them in the forest; and the monkeys sleep high up in the trees among the branches that are too slender to bear the leopard's weight, if he should think of climbing up in the night when he goes out hunting. 


\section{MUSOKE THE MOON-BOY}

YEARS and years ago in Uganda there was a woman whose banana garden bordered the high road, and every night the travellers who passed by stole fruit and vegetables out of her garden, and this made her very angry. So she took counsel with her old nurse, who lived with her, and they dug a ditch, and covered it with sticks, and branches, and earth, and leaves, and said to each other :

"The next thief who comes at night will tumble in."

The next evening the herdsman of the Chief was driving his cows home to the kraal, when one of them strayed into the woman's garden, and fell into the ditch trap and broke its leg. The cowherd was very angry and told the Chief, and the Chief sent for the woman, and said, "Why did you set a trap for my cow ?"

When the poor woman explained what she had done the Chief was still more angry, and said :

"You meant to kill my people. You are a wicked woman." And he ordered her to be beaten. The woman implored the Chief to have mercy on her, and he said : 
"Well, you may go home now, I will not beat you, but the next child you have shall be mine. If it is a boy I will kill him, if it is a girl you may keep her until she is twelve years old, and then she shall be my slave."

Very soon afterwards the woman had a child, and it was a most beautiful baby boy. She cried very much when she thought that her dear little baby would be killed; so she sent her old nurse to the Chief to say that it was a girl. The Chief said, "Bring the child here that I may see it."

When the nurse came back and told the woman, she cried more than ever; but just then a stranger passed down the road and turned into the garden to ask for a drink of water. She had a little baby tied on her back and she carried a roll of mats on her head. The nurse gave her a drink of water and said, "We are two women in great trouble." And then she told the stranger the story.

The stranger said, "I will lend you my little girl baby; go and show her to the Chief and save the life of your little boy."

So the nurse went again to the Chief's house, and when he saw the baby he said, "Tell the mother to bring this child to me when she is twelve years old."

Nobody suspected anything, and when the old nurse got home she packed up all their things, and at dawn the next morning they set out for Singo with the stranger who had been so kind to them.

The years passed, and they all lived happily 
in Singo, and the baby grew into a beautiful boy, and they called him Musoke, which means Rainbow. Every day Musoke took his goats on to the hillside and played on a reed pipe as he walked, and the goats skipped about and jumped, but some were staid old things, and walked sedately. This was the song Musoke sang in the morning when he took the goats out before the sun was hot.

Little black kids,

Little white kids,

Speckled and striped and brown,

I love them all

And they all love me,

Our life is happy and gay and free ;

Eat and sleep, and sing and play,

That is our life of every day.

Out to the hills when the sun is low

What we talk of who can know?

Home to rest when the sun is high

What do we dream of, they and I ?

Little black kids,

Little white kids,

$$
\text { etc. etc., etc. }
$$

In the evening, when he brought his goats home, he sang another song to them on his reed pipe.

Come home, come home, little Brothers,

The shadows are soft and long.

Come home, come home, little Brothers,

And I'll sing you a slumber song.

For the plantains are peeled in the kitchen

And over the fire they steam,

And the housewife has saved the peelings for you

As luscious and cool and green as they grew.

Come home, come home, little Brothers,

etc., etc. 
One day a messenger arrived from the Chief, who said, "Your little girl must be twelve years old now. The Chief has sent for her." The mother was very sad. She sent the old nurse out to the hills where Musoke was herding the goats, and said :

"Tell my child to come home by the back way and to sit in the kitchen hut till I have told him what to do."

Then she cooked food for the messenger, and said, "When you have eaten you shall see the little girl and take her away with you."

She dressed Musoke in a little barkcloth and put bracelets on his hands, and as she did so she told him the story of his birth, and said, "I have saved your life up till to-day, I can do no more. You must use your own wisdom"; and she told him a Luganda proverb; "It is no use asking the gods to help you if you dón't mean to run fast."

Then she led Musoke to the messenger, and said, "Here is my little girl, take her to the Chief." And she gave Musoke a present to take, a big hen, and some sem-sem seed in a packet of banana fibre-and the old nurse went with them carrying their roll of mats.

The Chief was very pleased with the little girl and the present she brought, and he gave the old nurse a hut, and said, "Take great care of this beautiful child, and see that she learns how I like my meals cooked, that in time she may be useful to me."

At first Musoke was very careful what he did, but he grew careless, and one day he saw 
a reed pipe on the ground, and in a moment he forgot everything and began to play his old goat song :

Little black kids,

Little white kids,

Speckled and striped and brown.

The people heard him in amazement. "Do girls play reed pipes?" they cried. "Who is this child?"

Musoke was frightened and ran home, and for some time he was very careful; but he soon forgot again, and one day he found some boys throwing stones into a wild plum tree. And he took the stones and threw them further and higher than any of the others. And the boys were amazed, and said :

"Can a girl throw? How did you learn to throw stones?"

Then Musoke was frightened and ran home; but the boys told their parents, and everybody began to talk about it, and at last it reached the ears of the Chief that there was something queer about the little girl who had come from Singo. And he sent to the old nurse and said :

" Come to the Council House to-morrow with the little girl and I will question you about the strange things she does."

When the nurse heard this she said to Musoke, "What have you done, my child? Now the Chief will find that we have been deceiving him, and he will kill us."

That night Musoke lay awake wondering what he should say when they questioned him 
in the Council House next day. And then he saw the moonlight shining through the chinks of the reed door, and he slipped softly out into the courtyard and sat down by a great stone. Everything was beautiful and peaceful round him. The hut threw a deep shadow across the courtyard, and behind it the wind sighed and the banana trees threw long flickering shadows which reached him now and then, and all round him the crickets were chirping, but no wise thoughts came to the poor boy. He sat huddled up in his little barkcloth against the big stone, and wondered what he should say in the Council House next morning.

A big fluffy owl flew past him and stopped in surprise. "Why are you not in bed, little girl?" he said.

"I am not a little girl," said Musoke; and he told his story to the owl.

"Ask the Moon to help you," said the owl, and flew away.

Musoke looked up at the Moon, but she seemed so far away and so cold and still.

A black bat flew squeaking past him and startled him a little. "What are you doing out of doors at night, little girl ?" he said.

"I am not a little girl," said Musoke, and told the bat his story.

"Ask the Moon to help you," said the bat, and flew on.

Musoke looked up again at the Moon; but she seemed still further away, and colder and stiller than ever. 
A big cricket hopped on to the stone by his side and gave such a loud chirp that Musoke quite jumped.

"Why don't you ask the Moon?" he said; " only the Moon can help you. But you must stand up, and shut your eyes, and stretch your arms high above your head when you speak to her."

So Musoke stood up and shut his eyes and stretched his arms high above his head; and then he laughed, for he felt his muscles swelling and was glad that he was a boy.

"Oh, dear Moon, have pity on me, and tell me what to do, and how to answer the Chiefs in the Council House to-morrow!"

Then from far away came a gentle voice. " Little boy, I have watched you for many years and I love you dearly. If you go to the Council House to-morrow and the Chiefs question you, nothing can save you-will you come and live with me in the Cloud Land? Once I had a little boy of my own, but he fell out of his cradle into the Great Lake and became an island, and since then I have been very lonely, for the stars are far away and never talk to me."

Musoke said, " How can I come to you right up in the sky?" And the Moon answered, "I will send a shower of rain and make a rainbow and you must climb up on that."

In a few minutes Musoke felt the rain beginning to fall and soon a beautiful rainbow appeared, and he said to the cricket :

" Tell my old nurse where I have gone, and 
give my greetings to my mother and tell them I am quite safe: I could not play at being a girl any more." Then he climbed up on the rainbow, and the Moon took him in her arms and laid him in the lovely pearl cradle where her own little boy used to lie, and told him not to lean out too far. In the morning no one knew where he had gone, and they never found him. But if you look up at the Moon you will see something like a cloud lying across it, and in England they call that the "Man in the Moon," but it is really Musoke the Moon-Boy in his cradle.

Perhaps some day you may see a moon rainbow. You may have to watch for many nights, for it is very rarely seen.

Some people have never seen one at all. 


\section{THE ELEPHANT THAT WANTED TO DANCE}

ONCE upon a time the big grey elephant gave a great feast and invited all the animals in the Mabira Forest to come to a beautiful glade (that no man had ever seen), and there they feasted in the moonlight and sang songs and made jokes and danced. There was one little hare who danced better than any other animal, and the big grey elephant said:

"Little hare, you are a marvel, you dance like a sunbeam."

There was a foolish young elephant at the feast, and he watched the hare dancing to and fro, and up in the air, and he wished he could dance too. He thought so much about it that for some days after the feast he was quite ill and he did not sleep at night, and at last his mother asked him :

" Have you any sorrow, my child?"

He did not like to tell even his mother what was worrying him, but he went off alone to the hare's house and implored him to teach him to dance. The hare was very surprised, and did not know what to say at first. He looked at the elephant's heavy legs, and he said kindly, 
"One must begin very young to dance, you elephants can do so many clever things which the other animals cannot do. I don't think it would suit your figure to dance." So the young elephant went sorrowfully home. When the

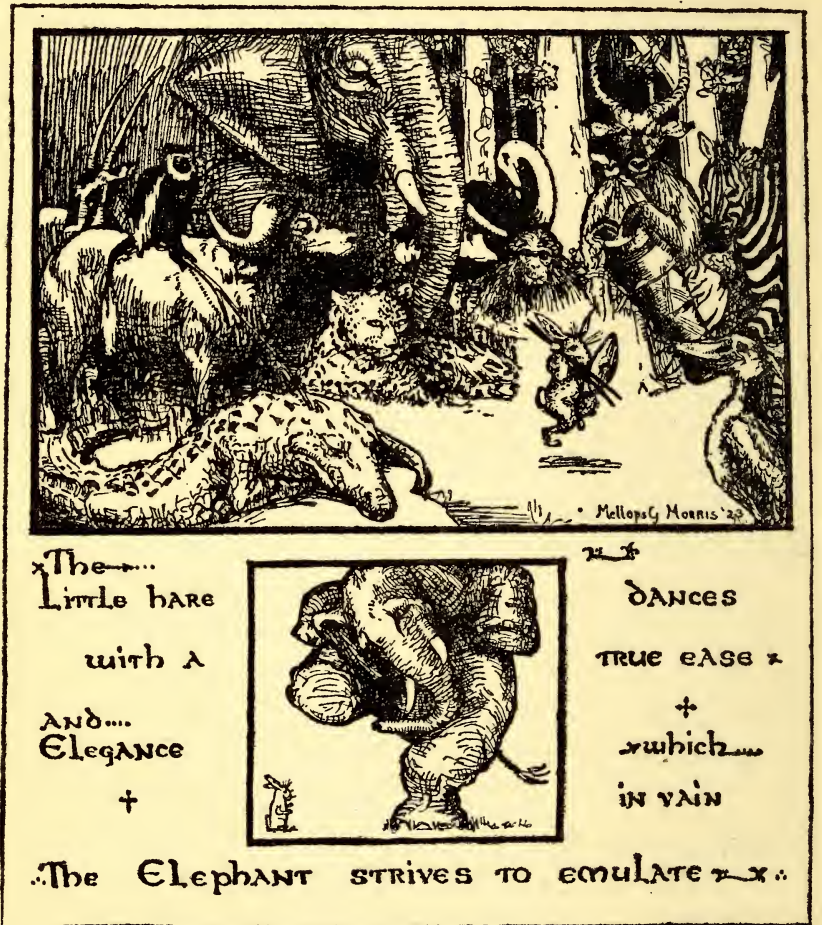

other hares heard of his visit they laughed very much, for who had ever heard of an elephant dancing? A week passed and the young elephant invited the hare to his house. He gave him a beautiful dinner and then said: 
"I must learn to dance. I think of this all day, and I dream of it all night. You must teach me to dance."

The hare looked at him in despair. "Your legs are too heavy," he said at last, " your hind legs are much too heavy." Then he went home rather annoyed. Again the elephant sent for him, but this time the hare would not go. $\mathrm{He}$ sent a message, saying :

"If you can get a doctor to cut off some of your heavy flanks, so that you will be lighter on your feet, I will try and teach you to dance."

The foolish elephant called in an ape, who professed to be a great doctor, and the ape cut all the flesh off his hind legs until only the bones were left and sewed the skin up again. The elephant sent the meat to the hare with a message :

"Now you will see that I am in earnest. When my legs have healed up we will begin the dancing lessons."

The hares laughed and laughed when they got the message ; but they said," Well, anyway we will have a good feast." So they sent for all their relations and had a big dinner of elephant steak with sem-sem sauce.

A few days afterwards the elephant sent an antelope with a message, "I am very ill indeed, my legs do not heal up, and my doctor thinks he had better sew on the flesh he cut off, so will you please send it back by the antelope." 
What was to be done? Some of the steak remained over from the feast, but they could not send it back for it had been cooked. The dancing hare said to the antelope, "Stay here, and dine with us, and afterwards we will talk over the business."

He said this to gain time and think of a plan. When the antelope tasted the elephant steak, he said, "This is very good meat, what is it ?" And the hare said, "Little rock conies that we catch on the hillside, if you like we will hunt some before you go home."

The antelope was delighted, and they set off; but the hare led him to a pit trap, and he fell in and was killed. When the antelope did not return the elephant sent a buffalo with the same message, and the hares played the same trick on him.

The young elephant was very ill indeed, but when the buffalo did not return he made a last effort and sent a crafty old leopard. None of the forest animals like the leopards very much, for they have such bad manners, and the leopard would not have gone on any message for any one, but he was a little afraid to refuse the young elephant who was a relation of the King of the Forest, so, very grumpily, he agreed to go.

The hares were terrified when they saw him coming, and the old mother hare said, "I suppose we must give him dinner; but I don't like it a bit, his table manners are awful."

The leopard gave the young elephant's message, sniffing and snuffling as he spoke and 
stopping every now and then to give a little grunt, and the hares kept up their courage all through dinner, and the dancing hare led him to the trap. The leopard had seen many traps, and he sniffed suspiciously round this one. Then he snarled at the hare, "You young villain," he cried, "I can see what you have done to the other messengers." He turned suddenly round in great anger, all his teeth bared, and would have caught the dancing hare, but he slipped away and ran down the hillside. There was a river at the bottom of the hill, and the hare ran in and out of the papyrus clumps where the leopard could not follow him, then hẻ let himself down into a water hole till he was quite wet, and ran back again. The leopard had lost the scent entirely, and was running up and down the bank sniffing and grunting. When he saw the hare so wet that his fur looked like a black rag he thought it was some queer creature that lived in the swamp. "Little wet animal," he cried, "have you seen a hare anywhere about?"

"No," answered the hare, "they seldom come here ; they live in the forests."

"I know that; you are stupid!" said the leopard rudely; and as the sun was setting and he was very hungry, he hurried back to tell the elephant his story; but when he arrived near home, he found much sorrow in the forest, for the poor foolish elephant was dead. And though the hares were really very sorry (for they loved their King, the big grey elephant, 
50 THE ELEPHANT THAT WANTED TO DANCE whose relation the young one was), yet they felt it really was his own fault for being so silly, and for believing anything an ape said; for no one in the forest, who has any sense, takes the advice of an ape. 


\section{THE MAN WHO KNEW TOO MUCH}

ONCE upon a time there was a man who had a most beautiful garden round his house. The soil was so good that everything in his garden was larger and better than any in the neighbourhood. His women did all the work, and he just showed off his garden to visitors, and because he was bad tempered they flattered him, and he became so proud and arrogant that one day he said :

"When Kintu, the first man, planted a garden he made some big mistakes. Had I been there I would have advised him very well, for look, this large pumpkin is growing on a small creeping plant, and those small plums on that great plum tree. I should have put the pumpkin on the plum tree, and the plums on a small plant."

And because his friends were afraid of him, they said how wise he was and flattered him more than ever. The next day he was sitting under his plum tree when a plum dropped down and hit him in the eye, and hurt him very much. He had to have his eye tied up and could not bear the light for some days. While he was sitting in the dark he had time to think, and he 
said to his friends, "What a foolish man I was to think I knew more than Kintu the first man, and how foolish you are to flatter me, for had a pumpkin fallen from the plum tree I might have been killed!" After this he became wiser and his friends left off flattering him. 


\section{THE STORY OF NSANGI AND THE APES}

ONCE upon a time, far away upon the mountains, there was a village in which the people were very unhappy, for some huge apes came every day and stole little children. There was one poor widow woman who had three little girls, and she hid them away in her house and never let them go out for fear the apes might see them. But every day her fears grew that she might lose her children, as other people in the village had lost theirs, and the little girls were growing weak and thin, because they never went outside their dark house, and never got any fresh air or sunshine.

At last the woman went to an old wise tortoise and asked him, "Tell me what I can do to save my children from the apes." And the tortoise said, "Apes never take children who are over twelve years old. If you can hide your little girls till then no apes will touch them, but I should advise you to take them away to a cave in the mountain side where they will get fresh air and room to run about."

So the tortoise showed the woman a cave. It was big and airy, and had a little entrance 
which could be closed by a stone inside and could not be opened from the outside, and there the woman took her three little girls and showed them how to close the entrance when she had gone, and she told them not to open the door to any one except herself. "I will come every day with a basket of food," she said, "and I will sing a song as I come so that you will know it is me. If any one comes to the door who does not sing my song do not open it."

The next day the woman brought a basket of food and she sang this song as she climbed up the mountain path :

Three in a cave,

Three in a cave,

Only three in a cave.

All day long while the sun is shining,

All night long while the moon is shining,

Only three in a cave,

Only three in a cave.

When the eldest girl was twelve years old the woman took her home and the two younger ones longed for the years to pass when they might leave the cave too (for they had no playmates but the lizards), but it was not safe till they were twelve years old, and the only glimpse they got of the outside world was when they opened the door for their mother, who now sang as she came :

Two in a cave,

Two in a cave,

Only two in a cave. 
All day long while the sun is shining,

All night long while the moon is shining,

Only two in a cave,

Only two in a cave.

Then the day came when the second girl was twelve years old, and only the little one, whose name was Nsangi, was left in the cave. She was lonely and cried very much, for now she had no one but the lizards to play with; but her mother said, "I will come earlier and stay longer with you every day, for now your sisters are at home and can do the work there.

Now, there was one old ape who saw the two little girls digging in their garden and wondered where they had come from, for he had never seen children in that house, and he watched and saw the woman go up the mountain path with a basket of food and as she climbed she sang:

One in a cave,

One in a cave,

Only one in a cave.

All day long while the sun is shining,

All night long while the moon is shining,

Only one in a cave,

Only one in a cave.

When she arrived at the cave Nsangi ran out to meet her, and the old ape hid behind a rock quite near. For several days he listened to the woman singing, and when he thought he had learnt the song he went to the cave door and sang it; but Nsangi heard it inside the cave and was terrified, for the ape's voice was like a hoarse old crow, and her mother's voice was 
like a bird's. The old ape was very angry, but he went away into the forest and found a young cousin of his who was a great mimic and could copy people's voices. Together they hid behind the rock and listened while the woman sang. Nsangi ran out to meet her mother, and begged her to take her home, for the ape had been to the cave. The woman was very distressed, but she said, "I must go home and tell your sisters, and I will stay with you till you are twelve years old. Your sisters can bring us a basket of food every day. I must go now and make arrangements."

When she had gone the apes went after her, sprinkling sharp thorns on the path, and then they hurried to the cave, and the young one sang, copying the woman's voice. Perhaps it was not exactly right, but Nsangi was too frightened to notice little mistakes. She was so glad that her mother had returned so quickly that she opened the door at once. The apes caught her and carried her away, right into the middle of the forest. She cried all the way, and wherever her tears fell little white flowers sprang into blossom. Meanwhile her mother had made all arrangements at home and was returning to the cave, but every now and then she had to stop to take a thorn out of her foot, and this delayed her. At last she reached the cave and found it empty, and the lizards told her what had happened and they told her to follow the trail of the little white flowers which were Nsangi's tears. 
The poor woman hurried back to the village and told the people what had happened, and the men came out with spears and knives to hunt the apes and they followed the trail of little white flowers right into the middle of the forest, and here they found a big tree which was the King Ape's Palace. Up this tree the apes had carried Nsangi, but as they dragged her up, her foot was cut on a sharp branch and the blood dropped down on to a creeper with thick green leaves, and wherever a drop of blood fell a beautiful crimson flower blossomed, like a convolvulus, only with thick soft petals. The men prepared to make a big fire round the tree, and when the apes saw that their King's palace was going to be burnt they all collected to defend it, and there was a great battle and all the apes were killed, and Nsangi climbed down the big tree and then the men lighted a fire and burnt it to the ground. That was the end of the King Ape's Palace.

And since that day apes have been afraid to go near villages, or steal children, for their mothers always tell them what happened to the King Ape's Palace.

But the birds and bees carried the seeds of the little white flowers all over the country, and the old people call them "Nsangi's tears," and you can still see the crimson creeper with flowers like a convolvulus, only with thick soft petals, but you must search for it in the deep forests. Some people have never seen it, but there are some people who never see anything. 



\section{SOLILOQUY OF OLD AGE IN A BANANA GARDEN}

DAwn has crept with many colours through the clouds,

But the daylight is young and very weak;

Chill round my hut lies the mist in broken shrouds,

And already forth I go my work to seek. Through the long hot weary hours I hoe the earth,

And the shadows of the trees grow short and small,

I am old and weak and tired and little worth,

All my life long I have been in some one's thrall.

$\mathrm{Oh}$, I smell the bitter smoke of many fires!

I have cooked and slaved and laboured in submission,

I have borne the fitful passion that soon tires,

I have suffered men's misusage and oppression ; I have spent myself as mother, wife,and daughter,

I have given them my all and now am cursed. How often from the stream I brought the water!

Yet none have ever asked me if I thirst.

MURIEL ROBERTSON.

Uganda, 1912

(Reprinted by permission of the Westminster Gazette.) 



\section{THE LAW CONCERNING FORTUNE- TELLERS; OR, "THE WISE LEPER"}

ONCE upon a time there was a woman who had a beautiful daughter whom she loved very much, and she was very anxious that she should find a nice husband. So many men wanted to marry the girl that the mother thought it would be very difficult to choose. There was one very nice Chief who lived in Kyadondo; but the mother was so worried about it that at last she went to a witchdoctor who told fortunes, and asked him to tell her whether the Kyadondo Chief would be a good husband for her daughter. Now, this old witchdoctor wanted tu marry the girl himself, so he made a great fuss getting out his cards, which were made of buffalo hide sewn over with shells and beads, and then he told the woman her fortune.

"On no account let your daughter marry the Kyadondo Chief." he said, "She will be most unhappy if she does. There is another man who will make her a good husband, but I cannot tell you who he is yet."

He then taught the woman to sing a song which he said would prevent her daughter from leaving home. It was a bewitched song. So 
the woman went home, and all the preparations for the girl's marriage to the Chief were made by her guardians, and at last messengers came from the Chief to take the bride to Kyadondo. As they started down the road the mother followed and sang the song the witchdoctor had taught her :
Alone, alone, alone.
Cook and carry and dig,
With never a day of ease.
My hut is dark, and the fire is low,
And the night wind sighs in the trees.
Stay with me, daughter mine,
Pity my eyes so dim.
Who is this stranger Chief,
That you leave me to go to him?
Alone! Alone! Alone!

When the bride's party heard this song they all stopped, and as the old woman went on singing, they turned slowly back and followed her to the house, and the girl went into her mother's hut and the messengers returned without her to Kyadondo. The Chief could not understand what had happened, so he sent other messengers for his bride, and the same thing happened three times. The messengers always returned without the girl, and could not give any account of what had happened. Everybody in Kyadondo heard about it, and they said, "The girl is certainly bewitched." Now, there was a leper man living near the Chief's house to whom he had been very kind, and the leper went to the Chief, and said, "Send me to fetch the girl, for I too know 
something about witchcraft; if the girl is to blame, I will not bring her, but if she has only been bewitched by some wicked person I will surely bring her to you."

So the Chief sent the leper man to fetch his

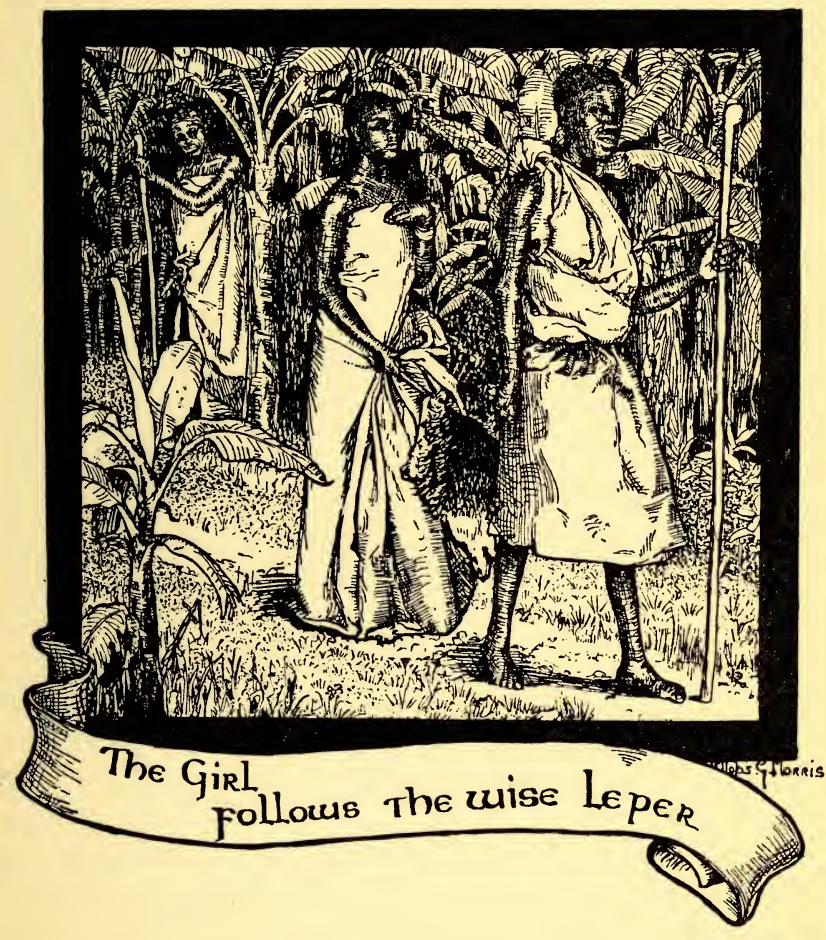

bride, and he set out, carrying a little goatskin mat and a reed pipe. When he came to the woman's house he sat down in the courtyard outside, on his little mat, and began to play his 
pipe. When he had finished they thanked him for the tune, and he got up and went away, but he left his little mat in the courtyard. When he was a little way down the road the woman noticed the mat, and she said to her daughter, "Look, the leper has left his mat! Go after him with it, but do not touch it with your hands, lift it with a stick and carry it to him like that.'

So the girl took a long reed and lifted the goatskin mat on it: and hurried after the leper. When she came near him she called:

"Look, my friend, here is your mat which you left in our courtyard. My mother has sent me with it."

The leper did not answer; but suddenly he began to sing, and as he sang the girl followed him down the road further and further from home. He sang this song :

Great and good is my Chief,

Full of grace are his words,

Wealthy the province he rules,

In gardens and flocks and herds.

There shall the girl he loves

Be happy beyond her dreams ;

Come with me, Maiden, and prove

All that this happiness means.

When the woman saw that her daughter did not return she went to find her, and saw her far down the road following the leper and still carrying his little goatskin mat on the reed. At once she thought that some trick was being played, and she hurried after them singing her bewitched song; but she was old, and her voice 
was too feeble to reach so far, and neither the girl nor the leper heard her. They went straight on, and came to the Chief's house in Kyadondo.

The Chief was much pleased, and all his people rejoiced (for they had felt it very much that he had been slighted by the girl and her people), and there was a great feast, and the Chief gave his bride a beautiful house and many servants, and she was quite happy. Meanwhile the poor old mother sat mourning in her hut, thinking that the girl would be very unhappy and that many misfortunes would come to her. But as time went on and the girl grew happier and happier, at last the woman sent a messenger to the Chief to tell him the whole story, for she knew that the witchdoctor had lied to her. The Chief went to the Capital and told the story in the King's Council, and they sent for the witchdoctor to hear what he had to say.

"My Lords," he said, "I have done wrong. I wanted to marry the girl myself, so I lied to her mother."

Then the King commanded that the witchdoctor should be killed. And that day a law was passed in the King's Council, and it was published throughout the country and everybody heard it :

"That if any woman goes to a witchdoctor to have her fortune told, a man of her tribe must go with her, and hear everything that is said."

This became a custom in Uganda in the old days; but now there is a new law, and no one 
may go to a witchdoctor at all, and if the police find a man telling fortunes they take him to prison. But still some people are foolish enough to go in secret, and have their fortunes told, even though they know this story. 


\section{THE HOLY MAN}

There was once a Muganda who made great friends with an Arab who came to Uganda to trade in ivory, and this Arab, who had travelled in many lands, told him interesting things about the people of different races. He told him how in some countries there were men who forsook the world and lived alone in great solitude, leading lives of study and silence, in which they learnt many things about the Great Spirit and the laws of the Universe, and these men became very wise and very holy.

When the Muganda heard this, he said, "I also wish to be a holy man and spend a life of solitude learning wise things."

So he said good-bye to all his friends and chose a hilltop where he built a grass hut under a great tree, and his wife left a basket of food at the foot of the hill every day, near the spring from which he fetched water. He spoke to no one, and no one saw him, and a long time passed.

Now, an old owl lived in the great tree, and he watched the man build his hut, and wondered what he had come there to do, but every day he watched, and nothing happened. The man just sat at his hut door and looked out over the 
hills and valleys until the sun set; then he fetched water and his basket of food and shut the door of the hut till morning. The owl had lived many years and had seen many strange things, but he thought that this man was the strangest of them all, so he decided to ask him what he was doing. He flew down and perched on a low branch and greeted the man below.

"Who are you ?" he said, " and what are you doing on my hilltop under my tree?"

The man answered: "I am going to be a holy man and learn much wisdom, therefore I have come here to live alone and learn about the Great Spirit and the wonderful laws of the Universe."

"What have you learnt so far?" asked the owl.

"I haven't learnt anything yet," said the man, "except that it is very hard to live alone and talk to no one. I am glad you have come to see me to-day, perhaps you can give me some advice."

The owl ruffled up all his feathers and then shook them down again (which is what all birds do when anything amuses them). "Certainly I can give you advice," he said; " the best way to learn wisdom is to solve riddles. I will ask you a riddle every evening before I go out, and you can think over it till the next evening. Every day I will give you a new riddle to guess, and you will become very wise. Here is one to begin with to-day, "I have a wife, everything about her is good; what is my wife?" 
The man thought and thought all the next day over this riddle, and at sunset the owl told him the answer. "It is a cow. The milk is good, the meat is good, the skin is good, the horns are good, the bones are good. There is nothing bad in a cow.'

Then he gave him another riddle, "I have a wife, she is very small, all her children are enormous." Again the man thought and thought all day but could make nothing of it, so the owl told him the answer. "It is a pumpkin seed. The seed is very small, all the pumpkins are enormous."

Then he gave him another riddle, "I have a wife, all her children are born white, but as they grow up they turn black." The man spent all day thinking over this riddle, and in the evening the owl flew down and told him the answer. "It is a wild plum tree. The plums are first white, as they ripen they become black."

This went on for many days, but the man never guessed a riddle, and at last the owl asked, "Do you feel you are learning much about the Great Spirit and the wonderful laws of the Universe?"

"No," said the man. "I am much disappointed. I had hoped to become very wise and holy, but I don't feel any different, only more lonely than ever."

Then," said the owl, "we will try another method. This evening before the sun sets we will go down and sit by the stream and see what we can learn there." So they went down the hill- 
side and sat by some bushes near the road from where they could see everything that passed, but were quite hidden. A man came down the road carrying a goatskin bag full of cowry shells, and he put this down while he filled his gourd with water from the stream, lower down where the water ran clear of the road. Another man came past at this moment, and he saw the goatskin bag, and he looked up and down the road and saw no one. So he picked up the bag, and ran off as fast as he could. Soon another man came down the road driving a sheep before him, and he stopped at the stream to let his sheep drink, and while he was doing this the first man, who had now filled his gourd with water, came to look for his goatskin bag, and he accused the owner of the sheep, saying, "You have stolen my bag of cowry shells."

The owner of the sheep was very angry, "Do you call me a thief ?" he cried. "You pass judgment without any reason. I have not seen your goatskin bag."

They grew more and more angry and finally they fought with their spears, and the owner of the sheep was killed.

When the owl saw that, he said to the Muganda, "Now, what have you learnt?" The man put his head in his hands, and said, "I am bewildered; an innocent man loses his property and becomes a murderer, and kills an innocent man, while the thief gets off free. What are the wonderful laws of the Universe?"

Then the owl said, "I will tell you the answer 
to this riddle too. The chief law of the Universe is, that the sins of the fathers are visited on the children. Now listen.

"The owner of the goatskin bag had inherited the cowry shells from his father, who was a rich man (but he had obtained his riches by killing a stranger secretly, and at night, and stealing all his goods). One day the father was found dead in his garden, and no one knew who had killed him. The murderer was the owner of the sheep, and justice has overtaken him. The man who stole the cowry shells is the son of the murdered stranger, so that really he has taken back his own inheritance; but he does not know this, and must be brought to justice. This is the way that evil spreads among men. One man is always avenging another's deeds. You will do no good by living on a hilltop thinking about it. Go back to your village and work, and you will then learn many things about the wonderful laws of the Universe. Two duties lie before you. You must bring these two evildoers to justice : the man who stole the goatskin bag and the man who killed the owner of the sheep." Then the man went home to his village, and next day he told the Chief what he had seen, and they brought the two men to the Council, and passed judgment upon them. And the man spoke so wisely and gave such good advice that all the chiefs in the Council were impressed, and his fame reached the ears of the King. And in after years he became the Chief Justice in the King's Council and decided all the important 
cases, and whenever he found a case too difficult for him, he went to the owl on the hilltop for advice, and the owl was always pleased to help him, and said, "You see that what I told you is true, solving riddles is the road to wisdom. It is a poor thing for a man to sit on a hilltop alone, thinking, but it is a great thing to help one's country by bringing evildoers to justice. 


\section{THE CHEATS OF KIJONGO}

ONCE there was a man who was a cheat, and he wandered round the country selling his goods in markets where no one knew him, and everywhere he cheated. One day he collected a lot of rags and bits of soft rubbish and made them into a neat roll, and put it all into a small piece of good barkcloth and rolled it up and tied it beautifully with broad barkcloth ribbons, until it looked like a roll of real good barkcloth yards and yards long. Then he went to a market called Kijongo. Now, there happened to come to the same market that day, another man who was a cheat. In Uganda the people eat white ants, and like them very much. They taste something like shrimps, and you cannot get them all the year round, only when the rains begin, twice a year. Then the people put a framework of reeds over the anthills and cover this with barkcloth and the ants come out and swarm in the barkcloth.

Then they are taken to the courtyards, all the wings are removed and the ants are fried, they are a great delicacy. The ants have long white wings which are thrown away. This cheat had collected a lot of ants' wings, and made them 
into a nice parcel with banana fibre, and on the top he put a few real fried ants and went to market, where he met the first cheat trying to sell his barkcloth.

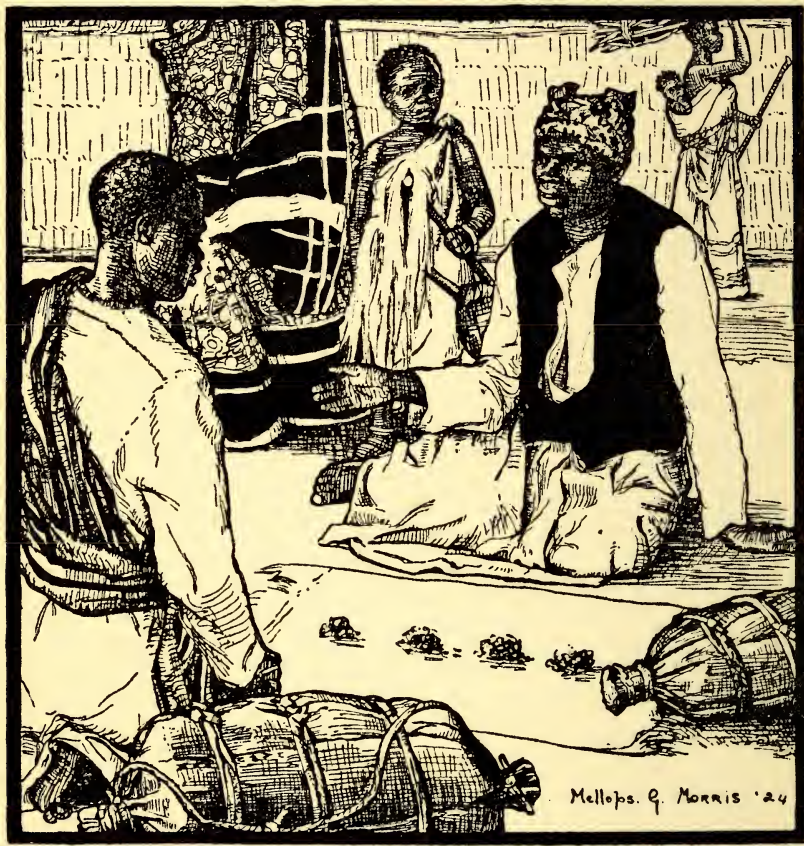

The

Cheats of Kijongo

"Will you buy white ants?" he said. The other man was hungry and said, "I don't want to buy them, but I will exchange my roll of bark- 
cloth for them "; and they agreed to exchange. Both went home very happy, but imagine their surprise when each opened his bargain and found he had been cheated.

This has become a proverb in Uganda. When a sharpdeal is doneand the dealer is disappointed, the people say, "It is a case of the cheats who met at Kijongo market," and if you know this story you understand what they mean. 



\section{THE STORY OF THE FROG}

IF a frog comes into a house in Uganda and you call a boy and say, "Drive that frog away," he will not do so, but he goes and calls a married man who drives the frog into the garden, and if you ask the boy :

"Are you afraid of frogs?" he will say, "No; but it is our custom to call a married man to drive one out of the house."

Now I will tell you how this became a custom. Long ago there was a widow who had a beautiful daughter, and they lived in a round hut in a banana garden. One day the giri saw a frog in the road. The poor creature was panting along in the sun, for it was midday and there was no shade. Every moment it grew weaker, and soon it would have fainted, but the girl picked it up and carried it into her shady banana garden and put it down in a pool of water where it soon revived. The next day as the girl was peeling bananas in the kitchen she heard a croak at the door and there was the frog.

"Good morning," he said, "I have come to thank you for saving my life. Some day I may be able to repay your kindness."

They became great friends, and the frog came 
every day to the kitchen and told the girl many stories about the animals. One day he noticed that she looked sad. "What is your sorrow?" he said. "Cannot you tell your friend?" So the girl told him. "My guardians are arranging for my marriage, and there are four men who want to marry me, and I do not know which to choose."

The frog said, "Now, I will give you some advice. Choose a man who has a kind heart: that is greater wealth than flocks and herds and a great chieftainship."

But the girl said, "How am I to know which one has a kind heart?"

Then the frog said, "We will make a little plan and find out. I know that you have a kind heart because you saved my life. I will help you to choose a man who is kind to animals. If he is kind to animals he will be kind to you."

So they arranged a plan, and the girl went to her guardian, and said, "I want to choose my husband for myself. I want the four men to come one by one, on an appointed day, and I will choose."

The guardian consented, and they arranged a day, and laid freshly cut grass down in the house, and the girl dressed herself in a beautiful barkcloth, and sat on a new mat, and three old ladies of her father's tribe sat near her to see that everything was done properly and in order. But they knew nothing about the frog.

As the first lover entered the porch the frog hopped out in front of him and croaked. He 
drove it away angrily, and went into the house, and the girl refused him at once. This happened to three young men and as the fourth entered the porch he stepped carefully over the frog, and when he had greeted the girl and the old ladies, he said, "There is a frog in the porch, does the croaking annoy you?"

"Not at all," said the girl ; "I like frogs."

"I am glad of that," said the young man, " for I like frogs too." Then they both burst out laughing, which was a very improper thing to do, and shocked the old ladies very much; but it made them friends, and the girl decided to marry him, and they lived happy ever after.

That is why a boy will never drive away a frog. He thinks that if he does so the girl he wants to marry will refuse him. 



\section{THE HARE WHO EARNED A COW AND A CHIEFTAINSHIP}

ONCE upon a time a large family of hares lived together in a beautiful forest glade. One day the old Chief said, "I want to make a feast before I die, but I have no meat; if only some one would give me a cow I would kill it and give you all a great feast, my children."

One young hare heard the Chief speak, and he said, "I will find a cow for the feast."

The others all laughed at him, "How will you find a cow?" they cried. "If you were to drive it through the forest the big animals would all try and take it from you, and how would you defend it?"

But the young hare said, "I will bring it, for I have a plan; but you must all help me, and lend me your things if I need to borrow them. First we must build a round hut and make a high fence all round it."

So all the hares set to work, and they built a round hut and a high fence,-and the young hare brought a hollow log into the hut, in which a family of bumble bees had made their home. They were very big bumble bees, and they all 
had very loud voices, and as they all talked together, the noise in the log was like the noise that a crowd of people makes outside the Council House when a big case is being tried by the Chiefs. Then the young hare went across the valley to the kraal and said to the chief herdsman: The King has built a beautiful camp in the forest and is going to make a big feast; he has sent me to fetch the most beautiful cow in your kraal; if you do not give it to me you will all be killed."

The herdsmen laughed very much, for they knew that the young hare was playing a trick on them; but they said, "You shall have your cow, but you must earn it. Stay with us for a week, and every evening when we return to the kraals you must tell us tales of the jungle, and sing us the forest songs, and sit with us round the fire at night, and amuse us for a whole week. The hare was delighted with the idea, and every evening when the sunset had faded and the soft shadows lay on the hills, when the cows had been driven into the kraals, and Kasanke, the little red bird whom the cows love, had been fed, the herdsmen would settle round the fire and listen to the wonderful stories which the hare told them, and the songs of the forest which every one loves to hear. For a whole week he lived in the kraals, and the herdsmen said he had earned his reward, and they gave him a beautiful cow with long sharp horns, and he set off for the forest driving it with a long reed. The first animal he met was the hyena. 
"I was coming to your house," said the hare. "The King wishes you to attend him at once, at his new house in the forest, with the tall fence round it."

So the hyena turned and followed the hare. As they went through the forest they met the lion and the buffalo and the leopard, and to each the hare gave the same message, and they all followed him till they came to the new house in the forest with the tall fence round it.

"Wait here," said the hare, " till I call you." And he drove the cow inside the fence. Then he beat the hollow log with his reed and all the bumble bees buzzed together, and the animals outside the fence crouched down in fear, for they thought a crowd of people were with the King. The other hares were frightened when they saw the big animals so near.

"What are you going to do?" they cried. "They will soon discover that you have deceived them, and the buffalo will trample us with her hoofs, and the lion will eat us, and the hyena will get the scraps." But the little hare was quite calm.

"Bring me a basket and an axe and a big knife and a pruning knife," he said ; and he went out to the trembling animals, who still crouched in fear, for the bumble bees had been thoroughly disturbed and were all saying what they thought about it, each trying to buzz louder than the rest of the family put together. "The King is going to give a feast," said the hare to the trembling animals, and you shall each have some meat, but 
you must earn it; the King has a task for each of you."

Then he gave the lion the basket and told him to fetch water from the stream; and he gave the buffalo the axe and told him to chop firewood from the rock; and he gave the leopard the pruning knife, and said, "Go into the jungle and cut a bamboo without a joint, the King desires a long straight bamboo without a joint." And he said to the hyena, "You are to skin the cow with this knife, but I warn you, if you so much as lick the meat you will be killed."

So the animals went away, each hoping to earn the King's favour; but when the lion saw the water pouring through the basket he was frightened, for he thought it was his fault, and he dropped the basket and ran away. The buffalo gave a hard blow at the rock with the axe, and of course the handle broke. He thought it was his fault, so he dropped the axe and ran away. The leopard wandered from one clump of bamboos to another looking for one with no joint, and finally when the sun was setting he was miles and miles away, and too tired to go back, and as he was afraid the King might punish him, he crossed a swamp into a new Province and made a new home there. Meanwhile the hyena began to skin the cow. He worked for some time, and then he licked his paws, and then he could resist the meat no longer. The hare was hiding near, and he raised the alarm, "The hyena is eating the King's meat!" And he beat the hollow log with his reed, and all the bumble 
bees buzzed together, and the hyena thought the people were coming out to kill him, so he dropped the knife and ran away, and did not stop running until he came to Kavirondo. Then the hares made a great feast for their old Chief, and they chose the clever young hare to be the new Chief, and rule the tribe, for they saw that, not only had he wisdom, but that he was calm in the face of danger, and this is a great virtue. 

SONG OF A MUHIMA HERDING CATTLE IN BUGERERE

From beyond the running river comes the Sun; Behold, oh ! my children, it is day. Forth across the plain I drive my lowing herd ; Gently my children keep the way. Many their hoofs, and many their long horns, And I herd, and I herd lest they stray.

Low voiced and never weary, from far places,

Far across the pasture of the plain,

Comes the wand'ring wind among my moving herd ;

Cool will it be in the time of the rain. And through their horns held high I hear it singing,

And I herd, and I herd in the plain.

From out the earth the night is coming fast;

Homeward to the East lies the way;

Close within the kraal, now still, upon the ground Rest my children, very weary, And I watch the shadows of their horns in the moon,

And I herd through my sleep till the day.

\section{MURIEL Robertson.}

Uganda, 1912.

(Reprinted by permission from the Westminster Gazette.) 



\section{THE LION-GIRL}

A LoNG way from Uganda, towards the Congo border, there is a tribe of shepherd people. They live in kraals with their cows; they plant no gardens and build no villages, but they move from place to place, driving their herds to good pasture and building kraals where they find it. The cows have long horns pointing upwards, and as the herds move across the plains the horns look like a forest, and although the hoofs make no noise in the rich soft soil the horns have a music of their own as they knock together, like many castanettes being played down in the plain.

There was once a woman of the shepherd tribe who had a baby girl, and one day, while the child was crawling on the floor, some chickens pecked at it. The child shook itself twice, and the mother saw, to her horror, that it became a lion $c u b$, and seized the chickens and ate them up; then it shook itself twice and became a little girl crawling on the floor. The woman was afraid to say anything to any one about this remarkable child, and as it grew older it ate young calves and goats. At last the mother spoke to her little girl :

"My child, you make me very ashamed of 
you, for you do such queer things. If any one were to know what you do the tribe would certainly, kill you, and probably they would kill me too."

The little girl answered, "I see that you are right. I will not play my tricks any more. I do not want you to be ashamed of me."

The years passed, and the child grew up, and the time came for her marriage. The arrangements were all made, and the bridegroom sent messengers to fetch her to his new kraal. When they arrived, the mother said, "I have not yet finished dressing the bride. Ask the messengers to sit outside and wait for a little while."

Now, with the messengers had come an old lady who was a granny in the bridegroom's tribe, and she was a very inquisitive old woman, and while the others sat down to wait for the bride, she slipped up to the kraal and listened to what the mother said to her daughter inside.

"My child, you will remember your promise to me and not play any of your tricks." And the bride answered :

"Do not fear; unless they anger me very much and I forget, I will never play those old tricks again."'

And the mother said, "Fven if they anger you, my child, do not play those tricks, they frighten me."

The old woman listening outside was filled with curiosity, and she returned to the waiting messengers wondering very much. Then the bride came out, and they took her to her husband's 
kraal. The lion-girl was a good wife and a good mother, and her children played no queer tricks, and the old granny watched and waited but nothing happened, and at last she went to the young wife, and said, "My friend, pity an old woman, and tell me something I want to know, for I cannot be happy by day and I cannot sleep at night, for thinking of what I heard your mother say to you about your tricks. What was it you promised not to do?"

Then the lion-girl was seized with anger, and she shook herself twice and became a full-grown lioness and growled at the old woman. And the poor old granny was so frightened that she went quite mad, and the lioness shook herself twice and became a woman again, and ran and called the people of the kraal :

"Come quickly, the poor old granny has gone mad in my hut."

Now, the old granny had a favourite daughter, and this woman came and took her away and took care of her; but every night, in her sleep, the poor old woman talked about the young wife and the lioness, until the daughter became suspicious and she told the other women in the kraal, and they went together to the lion-girl and asked her :

"What happened when the old granny went mad in your house, for she talks incessantly about a lioness?"

The lion-girl was seized with anger, and she shook herself twice and became a full-grown lioness and roared at the women, who ran away 
terrified. Then the lion-girl went away across the plain and was lost in the jungle, for she was afraid the men of the tribe would spear her, now that her secret was known.

All this trouble came about because the old granny was so inquisitive. 


\section{THE WONDERFUL GOAT}

ONCE upon a time there was a man called Kato who had a large herd of goats, and he noticed that one goat was larger than all the others. It grew and grew, and at last it was so enormous that people came from all parts of the Province to see it, and they said, "This goat is a fit present for the King, no one has ever seen its equal." Kato determined to go to the Capital and give his wonderful goat to the King. Now, in the mountains near his village there lived a band of robbers, who used to plunder passers-by and take their goods and sometimes kill them. So Kato was afraid to make the journey to the Capital alone, and his brother agreed to go with him, but first he went to the witchdoctor to have his fortune told, which was a very silly thing to do, as you will see.

The robbers had seen the enormous goat and wondered how they could steal it, and, unfortunately, while the chief robber was returning from the village market, he saw Kato going towards the witchdoctor's hut (for he lived alone on a hilltop). The robber knew of a short cut, and he hurried round and arrived first at 
the hut, and promised the witchdoctor a large reward if he gave certain advice to Kato.

When Kato arrived the witchdoctor said, "You are going on a journey, but you must go

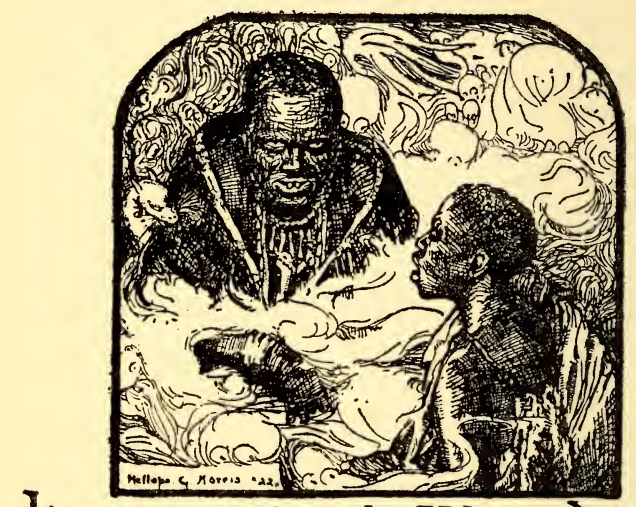

Kato consults the Ulitch Ooctor

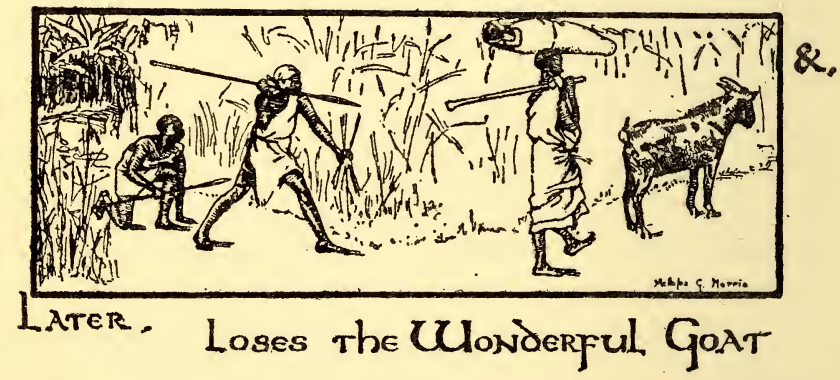

alone, and until you reach your destination you must eat no salt and drink no banana beer, if you do either of these things misfortune will overtake you."

When Kato returned home he told his brother, 
and he also told his wife to use no salt in the kitchen until he had started for the Capital. Then he made his preparations, and one morning at dawn he started out, driving his goat before him, with a gourd of water tied round his waist by a thong, and a parcel of food in a bag slung over his shoulder and carrying in his hand a spear wrapped round with plantain fibre (for no traveller may carry a naked spear).

By midday he had reached the mountains, where the road passed between great boulders of rock, on which the turquoise-blue lizards played all day. He was hot and tired, so he sat down in the shade to rest and eat his dinner. He was so hungry that at first he ate without thinking, but as he felt rested he realised that the dinner was very good, and suddenly he remembered the witchdoctor's warning, and he wondered if there was salt in it. The more he thought over it the more convinced he was that he had eaten salt.

He started off again on his journey much agitated, and he had not gone very far when one of the robbers met him, and after giving him a friendly greeting, said, "Why are you driving a pig? That is a very unusual thing to do!"

Kato looked at the robber in amazement. " A pig!" he cried. "I have no pigs! This is my wonderful goat I am taking to the Capital to give to the King."

"Oh, really!" said the robber; and he said good-bye very quickly and hurried away. Kato was still thinking that the man must have been 
at a drinking feast to say such an extraordinary thing, when another of the robbers met him. "That is a fine pig!" said the robber. "Where did you get it?

"It is a goat," said Kato; "my wonderful goat that I am taking to the Capital to give to the King."

The robber looked very much surprised and went on his way. Three more men of the robber band met Kato on the mountain path, and each one stopped in surprise and made some remark about his pig. Suddenly the witchdoctor's warning flashed across his mind: "If you eat salt or drink banana beer misfortune will overtake you."

"I have eaten salt, and my goat has been bewitched and become a pig," he cried; and he was so frightened that he left the goat and ran all the way back to the village and his home. When he arrived he told his wife and his brother, "I have been bewitched, I shall surely die."

The hot journey in the sun, the fright he had had, and the exhausting run home brought on a fever, and he died.

And the robbers took the goat and made a great feast and sent a large joint to the witchdoctor with the present they had promised him; but Kato's family not only lost him and the wonderful goat, but they were more firmly convinced than ever before that the witchdoctor was a marvellous man. 


\section{THE RIVER FAIRY}

A VERY long time ago a dreadful plague swept through Uganda, whole provinces were laid waste and returned to jungle, for those who had possessed the land had died, and there were none to inherit the villages and gardens. In one village every one died except one little girl, and she wandered away down the road till she came to the river Nile. She had a very, very, very long name, which means "Glory." She sat down by the river very lonely and miserable, and while she was wondering what to do a fisherman came past. The child told him her story and he was sorry for her, and took her home with him, and his wife was kind to her, and for a little while they lived happily together. But the dreadful plague swept on and killed the fisherman and his wife, and again the little girl sat desolate and hungry by the river Nile. Suddenly she saw the tail of a great fish as it turned in the water. Glory was a little frightened, for she had never seen such a huge fish in the river before. To her surprise, as it came nearer, she saw that it had a woman's head and that half its body was that of a woman. The fish spoke to her: 
"Do not be afraid, little girl; I have seen you here very often, and I want to be your friend. Tell me your sorrow."

Glory did not feel frightened any more; she said :

"I am all alone, every one I know has died of the plague. I cannot dig and plant a garden all by myself, and I cannot live all by myself, and I don't know what to do." And she began to cry.

The fish-woman came nearer and pulled herself up on a rock, and Glory stopped crying to look at the beautiful tail covered with goldenbrown scales which flashed in the sunlight as the drops of water ran off it :

"What a beautiful tail you have!" she said.

"I am the Fairy of the river Nile," said the fish-woman, "and we all have beautiful tails in my country.'

"Where is your country?" asked Glory.

The River Fairy pulled herself into a more comfortable position on the rock and began :

"You see the Great Lake which stretches away above the Ripon Falls? when you look at it you see only the top of a wonderful land. Under those blue waters, far, far down lies a beautiful country. It is not like the country you know, but it has fields of soft green seaweed, forests of great sea-palms, sea-flowers of every colour and shade. In the middle of this country is the Lake City where the King of the Fishpeople lives, a wonderful city of caves cut in the rocks. There are long streets full of blue 
water, and the caves are the homes of the fishpeople. There is one cave larger and more beautiful than the others, and that is the King's Palace. All the fish-people are his servants, we each have our own work, and we all obey his orders. My work is to watch the entrance of the river Nile. All day I live in my cave under the Falls, and at sunset I swim by a passage through the rock into the Great Lake above, and go to give my day's report to the King of the Lake City. Very early in the morning I come back, and at dawn I am in my cave again at work. There are other fairies who guard the entrance of rivers which flow into the Great Lake, but mine is the only river which flows out of it. My river dashes over the Falls and hurries away to the Rapids, and on and on, through deserts and plains till it reaches another Great Sea."

"I should like to see your cave and your Lake City," said Glory.

"Can you swim ?" asked the River Fairy.

"No," said Glory, " but I could sit on your back.

The River Fairy laughed. "I am afraid that would not do, for we should have to swim under the water, and you would lose your hold and be drowned. Unless you consent to become a fish-maiden you can never see the Lake City, and my cave under the Falls."

"How can I become a fish-maiden?" asked Glory.

"It needs a great deal of courage for a. 
mortal to join us. I should have to cut off your feet, and from them a tail would grow."

Glory looked down at her little brown feet and dug her toes in and out of the soft sand, and said :

"I don't want my feet cut off."

"I must not stay any longer now," said the River Fairy. "I will be here again at daybreak." And she slipped off her rock into the foaming water and disappeared under the Falls.

When Glory was left alone she felt very unhappy and longed for the River Fairy to come back. She was very hungry too, and went to look for some food; but the gardens were empty and over-grown, and she could hardly find any fruit. Every now and then she looked down at her little brown toes, and said to herself :

"I don't want my feet cut off."

She watched the big red sun drop down behind the hills, and quickly the darkness fell round her. She crept into her cold, empty hut, and shut the reed door, and tried to get warm under the barkcloths; but the night was damp and foggy, and she shivered all alone. She heard the owls hooting to each other, outside, and the bats squeal as they hung on to the porch of the hut for a minute or two on their way to hunt, and poor little Glory sobbed bitterly, worn out with cold and hunger and loneliness. Suddenly she sat up.

"I will give up my little brown feet and go and live with my kind friend the River Fairy," 
she said to herself. She drew aside the reed door, and the frightened bats fled squeaking away into the shadows. She huddled her little barkcloth round her and crept down the path to the river, but just as she was reaching the bank a huge form loomed out of the mist and a cow-hippo came puffing and blowing and snorting up the path. Glory hid behind a bush and did not dare to move until she saw the dawn begin to break. Streaks of light flashed quickly across the sky, the bats darted backwards and forwards, the birds began to twitter and wake, and suddenly the sun rose. Glory hurried down to the river, and there sat her friend the fish-woman on the same rock, her golden-brown tail catching the rays of the rising sun.

"Oh, dear River Fairy," she cried, "I have changed my mind! I want to come and live in your cave and be your little girl."

Then she gave such a start that she nearly fell into the river, for she heard the same puffing and blowing and snorting coming down the path.

"It is only my great friend the cow-hippo," said the River Fairy.

The huge hippopotamus stopped and looked at the child :

"I thought all the mortals had died," she said.

"Only this little girl is left," said the River Fairy, "and she wants to become a fish-maiden and live with me." 
"Very wise of her," said the cow-hippo; " but she looks very hungry."

Poor little Glory was quite worn out with cold and hunger and the long hours spent on the river bank, and when she tried to get up she fainted.

The River Fairy and the cow-hippo did everything they could, for they were much distressed, they laid her in the warm sunshine on the soft sand and rubbed her hands and feet.

"We must get her some food," they said to each other.

"I have only raw sweet potatoes," said the cow-hippo, " and she can't eat them uncooked, for I have often seen the fires which mortals make. If we could get some sweet bananas she might eat those."

By this time the sun was well up and the whole world was awaking to the life of a new day. A cheeky-looking monkey swung himself down by a branch and screamed :

"How have you slept? How have you slept, Hippo and Fish-People."

" Come here at once," commanded the cowhippo; and the monkey turned a somersault and landed on the ground.

"Do you know the golden sweet bananas that mortals eat?" asked the cow-hippo.

" Of course I do," said the monkey," I have eaten bunches of them myself."

"Then go and fetch a bunch at once," said the cow-hippo.

The monkey scratched his head, then he 
looked up at the sun and blinked his eyes, then he scratched his shoulders and said meekly:

"Did you ask me to do anything?"

"Now, listen to me," said the cow-hippo firmly, "you are to go very quickly, and fetch a bunch of golden sweet bananas."

"Where from?" asked the monkey.

"From where they grow," said the cowhippo.

A flight of grey parrots had come over from the nearer islands in search of food, and as they rested for a moment on a tree near, they heard the conversation. One of them flew down and said to the cow-hippo :

"It is absolutely useless to send the monkey on any errand alone, he will simply forget what he has set out to do. We will go with him and see that he brings the bananas."

"I don't want you," said the monkey sulkily; but in a minute he began to laugh and jump about and dance and forgot that he was offended. All the animals know how silly the monkeys are in this way, but they forgive them many things because they are so funny. The monkey went off with the parrots and every time he stopped to play they shrieked at him :

" Remember the bananas." And at last they brought him back safely with a big bunch of ripe golden fruit, and Glory ate them until she was hungry no more. Then she cuddled down in a nook in the river bank and went fast asleep. While she slept, the cow-hippo and the River 
Fairy watched over her, and when she woke they asked her :

"Do you still want to be a fish-maiden?" And Glory looked at her little brown feet and replied :

"Yes; to-day I will come to you. I cannot go back to my cold hut any more."

Then the River Fairy gave her some seaweed to eat. It tasted very bitter, but as soon as she had eaten it she fell asleep, and while she slept the River Fairy bound her legs together with broad bands of seaweed and cut off her little brown feet with a sharp shell, and at once a little tail appeared growing from them. Then she slipped into the water and carried Glory to her cave under the Falls, and laid her on a lovely soft bed of seaweed. There she slept for a whole week and every day her tail grew more beautiful, and when she woke it looked like mother o' pearl. She was very hungry when she woke after her long sleep, and the River Fairy gave her seaweed and sea-fruit to eat, and now it did not taste bitter, for she had become a fish-maiden and could open her eyes under water and swim about and turn her tail in the white foam. Then the River Fairy took Glory to the Lake City and presented her to the King of the Fish-People. They swam down the blue streets bordered by caves and sea-palms; beautiful sea-plants and flowers were on every hand, and then they reached the King's Palace, and bowed before the King. The King was an old, old man who had ruled the Fish-People for hundreds of 
years. He looked earnestly at the little girl and spoke :

"Little Fish-maiden, you are to live with the River Fairy and guard the Falls of the Nile. You are to learn her work so that in years to come you too may help us in keeping our beautiful Lake Country pure and clean, that the water which dashes over the Falls may carry greetings from the Great Lake to the Great Sea which lies far away to the North."

And now in Uganda, when the sun has set and the fires are lighted in the fishermen's huts near the river Nile, and the people have eaten their evening meal and gather round the fire, they tell stories ; perhaps a fisherman will say :

" Once I saw a big fish near the Falls, as big as a woman, with a head and shoulders and arms like a woman."

And the others will say:

"How wonderful! how wonderful!"

But in their hearts they think:

"He is lying, he did not see this fish."

But the fisherman is not lying, for he has seen Glory, the Fish-maiden, who is now the River Fairy and guards the Ripon Falls. Here the Great Lake sends its blue waters over the rocks, and they hurry away foaming towards the Rapids, and on and on over the deserts and plains until they reach the Great Sea which lies far away to the North. 



\section{THE ROYAL PUFF ADDERS OF BUDO.}

OUTSIDE the main gate of the Lubiri (as the dwelling of the King of Uganda is called) stands a round grass hut. In it burns a fire, and it is the duty of a special Chief to see that this fire never goes out during the King's lifetime. In the old days, when the King died the Katikiro announced to the people, "The fire has gone out." Then the Chiefs chose a new King from among the Princes and killed all the others to prevent a rebellion. (These customs have died out, but the fire still burns in the little grass hut near the gate of the Lubiri, and if you go there you will see it.) When the Chiefs had chosen a Prince they took him to Budo Hill. On this hill there are some great trees, they can be seen for many miles round, for they stand out clear against the sky. Under these trees a little hut was built, and here the young King had to pass the night alone, before the coronation ceremonies. A long time ago a certain King of Uganda died and a young Prince was chosen to succeed him, and was taken by the Chiefs to Budo Hill. He entered the hut under the sacred trees and prepared to keep the vigil. The night fell, and the 


\section{THE ROYAL PUFF ADDERS OF BUDO}

hut was in complete darkness. All around him was silence broken only by the sounds of the night, the chirping of a cricket or the occasional
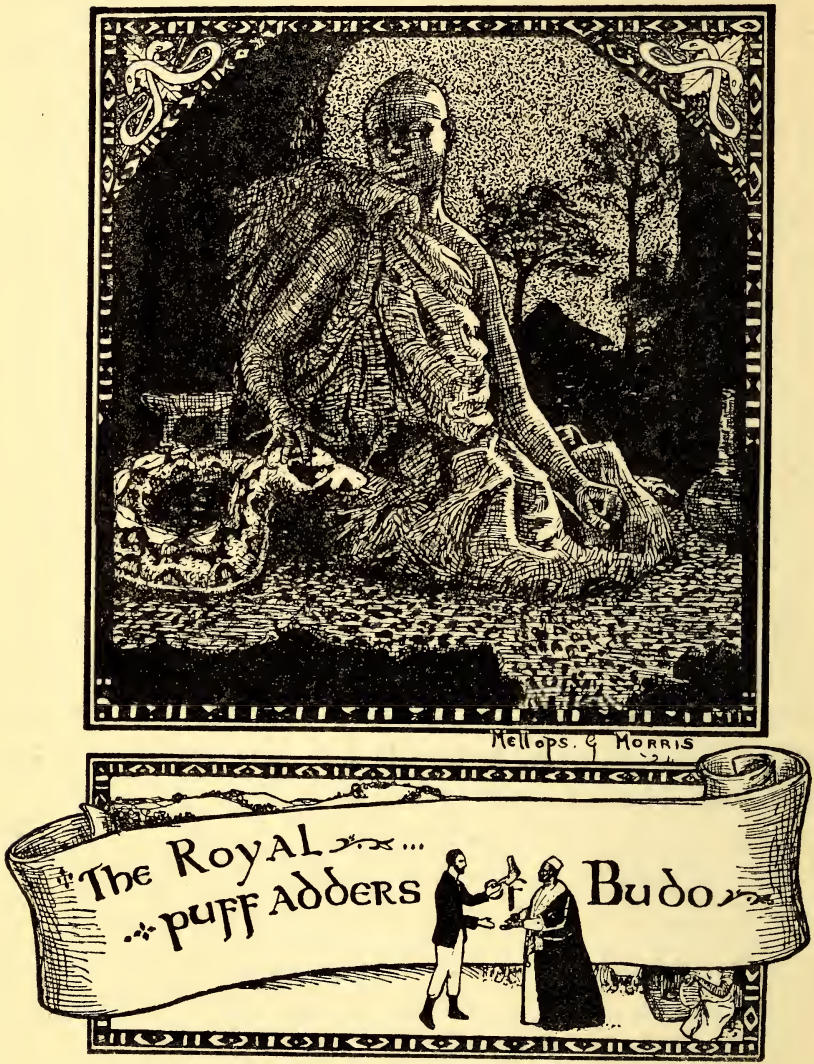

squeak of a bat. The young King sat alone and meditated on the life that lay before him. Suddenly he heard a rustle in the grass walls of the 
hut and fear gripped him, every hair seemed to stand on end, for he knew that a snake had crept into the hut and that he was alone with it in the darkness. The boy was no coward, and he would have faced a big animal with courage. But a snake is the foe of every man, and brave men fear to meet one in the dark. He sat still not daring to move, and suddenly he heard a hissing voice near him say:

" Young King, put out your hand and lay your fingers on my head, for I wish to talk with you, and I am deaf, and can only hear you through the touch of your fingers on my head."

Trembling with horror the boy obeyed, and in the dark he groped for the flat chilly head of the snake and laid his fingers on it.

Immediately the snake spoke again. "I am the King of the Puff Adders. Budo Hill is our tribal home. Many of us have wandered into the other provinces, but we come here to die in our old age. Everywhere that men see us they kill us, for they fear our poison, but we have not killed your people in anger. We are deaf, and cannot hear the approaching footsteps of man; when they tread on us we defend ourselves."

The young King listened in silence, and then asked :

"What do you wish me to do?"

"I ask you as a favour to grant us a refuge. Send a command throughout the country that no man is to kill a puff adder on Budo Hill, then we shall have a refuge and a place of safety, and we will be your servants and serve you well." 


\section{THE ROYAL PUFF ADDERS OF BUDO}

"How will you serve me ?" asked the King. "Can snakes do work?"

"Not the same sort of work as men, but we can be very useful to you, for we can foretell the future better than all the witchdoctors, for it is we who give them their knowledge. If you make friends of us the witchdoctors can never harm you."

The young King was silent, thinking what he would do, for he feared the witchdoctors, and would gladly have rid himself of their tyranny. At last he spoke :

"I will give the command you wish as soon as I am proclaimed King, and this Hill of Budo shall be your refuge and place of safety; but you must give me some proof of your words, for how do I know that you are not lying?'

The King of the Puff Adders thanked him in the same low hissing voice, and then began:

Young King, I will tell you the future of your country. Mark my words well, for all that I tell you will surely come to pass. You are proud and arrogant, and you have much to learn. You will learn much as the years pass, but your people will call you, "He who causes the tears to flow.' You have much wisdom, and you will make good laws and benefit your country, and you will regret the hardness and cruelty of your youth. Strangers will visit your land and teach you many things, some bad and some good. But the day will come, young King, when your Chiefs will come and tell you that notable 
strangers have arrived in Uganda, and the Chiefs will ask you :

" "Shall we kill these men, who are different to any men we have seen before?'

"On your answer will depend the whole future of your country, for these men will be the forerunners of a great force which your sons and your grandsons will not be able to resist. They will teach you new wisdom and new work, and they will bring new gods before whom the witchdoctors will disappear. Test these strangers by whatever means you will, but know this, that on your treatment of them the generations to come will judge you wise or foolish. What will you do that day?"

The King said :

"If I receive them well and they are the forerunners of a great force, they will eat my kingdom."

"They will not eat your kingdom," answered the puff adder, "but they will rule over your land, your sons and your grandsons shall be Kings of Uganda but in a new era-one of which your ancestors never dreamed. What will you do?"

"If I kill them, what will happen?" asked the King.

"More of their countrymen will follow, but on your treatment of these first comers the future of your land depends."

The King was silent for a long time then he said sullenly:

"I will give up my country to no man, but 
when these strangers arrive I will receive them kindly."

In the morning the Chiefs came and the young King left his hut, and after the coronation ceremonies were over and he entered on his new duties, to the surprise of all the Chiefs his first proclamation was this, that no man should kill a puff adder on the Hill of Budo.

The years passed in wars and short times of peace. The young King was proud and arrogant, and though he made good laws and governed well he was so cruel and hard that his people called him, "He who causes the tears to flow." Arabs visited Uganda and brought many new things and new customs, and new cruelties followed in their wake. One day the Chiefs came to the King and said :

"Some strangers have arrived from the South ; they are not Arabs, and they are different to any men who have come here before. Shall we kill them?"

The King heard their words in silence, he sat with bowed head lost in thought. Vividly before him grew the memory of a night long ago when he had sat in a dark hut on Budo Hill with his fingers on the head of a puff adder. Again he heard the hissing voice as it said :

"Know this, that on your treatment of them the generations to come will judge you wise or foolish. What will you do that day?"

Silently the Chiefs knelt before the King waiting for him to speak.

His reign passed before him in one clear 
picture after another. He had made his country great, he had made wise laws, he had been hard and cruel but strong, the puff adder had spoken truly. Again he heard the question, "What will you do?"

Slowly he raised his head, but he did not look at the waiting Chiefs, his eyes seemed to look far beyond them into the future.

"Receive these strangers kindly," he said in a low voice. "Bring them here to me, and let no man do them any harm."

Many years have passed since those old days. The great trees still stand on the Hill of Budo, and can be seen for many miles round. The hilltop has been cleared and houses and gardens stand where before was only jungle, and in making this change many puff adders were killed by the workmen, for men had long since forgotten the first proclamation made by a young King in the days gone by.

Yet to-day, if you visit the spot under the great trees where once the hut built for a King's vigil stood, you must walk warily, for a gleam of red and gold in the grass will warn you that the puff adders still hold to their ancient refuge and claim the privilege once granted by a King to live on the Hill of Budo. 
PRINTED IN GREAT BRITAIN BY WILLIAM CI.OWES AND SONS, LIMITED, LONDON AND BECCLES. 



\section{BOOKS FOR \\ BOYS AND GIRLS}

FROM SIX TO SIXTEEN

BY

POPULAR WRITERS

ILLUSTRATED BY FIRST-CLASS ARTISTS

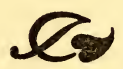

THE SHELDON PRESS

LONDON: NORTHUMBERLAND AVENUE, W.C. 2 And of all Booksellers 


\section{Books for Boys $\&$ Girls}

\section{Arranged under Authors' Names}

Baldwin, Mary. Terry and the Ancestors. 1s. 3d.

Barham, A. M. The Namesake of the King. A Tale of the Last Years of Cœur-de-Lion. 2s.

Barnard, Marjorie C. Westcote Towers. 2s (A school story.)

Donald Marston. A Sequel to "Westcote Towers." 2s.

The Misfortunes of Tony. 1s. 3d. (A humorous story of small boy life.)

Bearne, Mrs. Catherine. In Perilous Days. A Tale of the French Revolution. 2s.

The Cross of Pearls. A Tale of the Hundred Years' War. 2s.

Bolland, Margaret J. M. A Little Pair of Pilgrims. 2s.

Bramston, M. The Thorn Fortress. A Story of the Thirty Years' War. 1s. 6 d.

Brave Dame Mary ; or, The Siege of Corfe Castle. 1s. $6 \mathrm{~d}$.

Bridges, T. C. The Bush Boys. A Story of the Australian Desert. 1s. $6 \mathrm{~d}$.

Brodie, F. Callender. Skirl o' the Pipes. A Modern Fairy Tale. 3s. 6d. (An entrancing book which has a charm and originality all its own.)

Brough, Frederick. The Treasure of the Red Peak. A Tale of the Cordillera. 2s.

The Cave-Men of Dulvercoombe. 2s. (Amusing adventures of two boys.)

The Dragon's Eye. A Tale of the Eastern Seas. 2s. 6d.

Channon, E. M. The Cotton-Wool Girl. 2s. 6d. (A school story.)

The Surprising Holidays. 2s. (Adventures in a country house.)

Chatterton, E. Keble. The King of the Air. 3s. 6d. (A thrilling story of adventure.)

Clare, Austin. The Carved Cartoon. A Picture of the Past. 3s.

Comfort, John. Don's Doings. 1s. 6d. (A story of life in Western Canada.)

Matt Desmond's Bit. 1s. 3d.

Nobby: A Son of Empire. 1s. 6d.

On His Own. 1s. 3d. (Adventures of an English boy in Canada.)

Toby's Luck. 1s. 6d. (A story of gold mining in Western Australia.) 
Cooper, Mrs. Frank. True to the King. A Story of the New Forest in 1647. 2s.

Cowper, Edith E. The Captain of the Waterguard. 3s.

Hunted and the Hunter. 1s. 6 d. (The joys and perils of a camper's life in Canada.)

The Crows' Nest. 2s. (A capital girls' story.)

The Invaders of Fairford. 3s. (A story of the Cromwellian times.)

The Moonrakers. 3s. (A story of smugglers.)

The Mystery of Castle Veor ; or, The Spies in our Midst. 2s. 6d.

Two on the Trail. A Story of Canada's Snows. 2s.

Wild Rose to the Rescue. A Story of Girl Guides. 2s.

Crake Rev. E. E., F.R.H.S. Dame Joan of Pevensey. A Sussex Tale. 2s.

Henry Duquesne. A Sussex Romance. 1s. 6d.

The Royalist Brothers. A Tale of the Siege of Colchester. 8s.

Davidson, H. B. Jerry and Joan. 1s. 6d. (A story of boy and girl life on a country farm.)

The Castle Tea-Garden. A Story of Girl Guides. 2s. 6d.

Pat of Whitehouse. A Story of Girl Guides. 2s. 6d.

Peggy Pemberton, Brownie. 1s. 3d.

Peggy's School Pack. 1s. 6d.

The Ardice Fortune. A Story for Girl Guides. 2s. 6d.

The Camp Across the Road. 3s.

The Guides make Good. 3s.

Meg and the Guides. A Country Story. 2s.

Drury, C. W. C. The Mystery of the Gap. 3s. 6d. (A book to delight all boys.)

Farmer, F. Lethbridge. Told by the Twins. 1s.

Fenn, G. Manville. In Mid-Air. A Tale of 1870. 1s.

Forester, F. B. Harter's Ranch. 2s. 6d. (A story of adventure.)

Forrester, Anne. The Purple Rose. A Story of Italy in the Fifteenth Century. 1s. $6 \mathrm{~d}$.

Fox, A. Wilson. Diana's Decision. A Story for Girls. 3s.

Charmian : Chauffeuse. A Story of a Girl's Adventures in the Great War. 3s. 6d.

Greig, Norman P. The Cromer Street Purty. 1s. 6d. (A story of child life in a slum.)

Grey, Amy. Jack's Baby. 1s. 3d.

Vita. The Story of a Charming Little Girl. 2s.

Dick's Debt. 1s. 6 d.

Grey, Wallace. The School Over the Way. 1s. 3d. 
Hardwick, J. C. Master and Man. A Story of the Peasants' Revolt of $1381.2 \mathrm{~s}$.

Harrison, F. Bayford. The Treasure of Spanish Villa. 1s. 6 d.

Harrison, F. Sea Scouts Afloat. A Story of the Great War. 2s. 6d.

Haverfield, E. L. A Brave Endeavour ; or, The Proving of Ysolt. $3 \mathrm{~s}$. Who are the Cromlyns? 3s. (A capital story about young people.)

Hawtrey, L. Castle Cornet. A Story of the Channel Islands. 2s.

Hayes, Nancy M. The Boy from Nowhere. 1s. 6 d.

The Runaway Caravan. 2s. (Holiday adventures in a caravan,)

The Lone Shanty on the Hill. An Adventure Story for Children. 2s.

The Lost Cave and Those Kennards. 2s. (A story of lost treasure,)

Traoked on the Trail. 2s. (A charming tale of three children.)

Hedges, Sid. G. Tales of Pendlecliffe School. 1s. 6d. (Exciting adventures which do happen from time to time in school life.)

Henty, G. A. The Plague Ship. 1s.

The Ranche in the Valley. 1s.

Herbertson, Jessie Leckie. Another Pair of Shoes. 3s. 6d. (A school story in which the development of character is cleverly depicted.)

Heward, Constance. Rolf's First Earnings. 1s.

Tommy's Little Grains of Sand and other Stories. 1s. 3d.

Sunshiny Stories. 1s.

A Handful of Happiness. 1s.

Faithful Teddy. Is.

Kitty's Tea Party. $1 \mathrm{~s}$.

Stories for the little ones.

Higginson, John A. A Strange Craft. 2s. 6d.

When Duty Called. 1s. 6d. (A yarn of shipwreck and adventure.)

Hobart-Hampden, Mrs. The Cave of Hanuman. Rainbow Series. 2s. Little Prince Tota. A Tale of the Himalayas. 2s. $6 \mathrm{~d}$.

Hollis, Gertrude. Uncle Michael's Story. A Tale of the River Amazon. 2s.

Hutchinson, M. F. Three in a Bungalow. 2s. (For girls.)

Jackson, Alice F. Heroes of the Chitral Siege. 1s. 6 d. A Brave Girl. A Story of the Indian Mutiny. 1s. $6 \mathrm{~d}$. With Mahdi and Khalifa. 2s. 6d. (A story of General Gordon.)

Jackson, Alice S. Oggie and the Sea Fairies. 1s.

Queen Caroline. 18.6d. 
Jackson, Lucie E. Norah with an "H." 1s. 6d. (The story of a little girl.)

Judd, Alfred. The Secret of Marsh Haven. A Story of School Adventure. $2 \mathrm{~s}$.

The Raiders of the Pool, and other Yarns. 1s. 3d.

The Land of the Firestone. A Story of Adventure in the Deep Forests of America and upon the High Seas. 2s.

The Track of Danger. Major Brand, his son Dick, and stalwart O'Flannel in New Adventures all round the Globe. 2s. 6d.

Wrens on the Trail. 1s. 3d.

Wrens to the Rescue. 1s. 3d. (Detective and other stories.)

Yarns by the Fireside. 1s. 6d. (For rollicking, unsophisticated fun these yarns will be hard to match.)

Kingston, W. H. G. The Cruise of the Dainty. 2s. 6d.

The Frontier Fort. 2s.

The Gilpins and their Fortunes. A Tale of Australia. 2s.

The Mate of the Lily. 2s.

Ned Garth. 3s. (A tale of the slave trade.)

Owen Hartley ; or, Ups and Downs. $3 s$.

Sunshine Bill. 2s.

The Two Shipmates. 2s.

Kirke, Violet T. When the Clock Strikes. 2s. (Historical tales in which the striking of a clock plays a descriptive part.)

Lampen, C. Dudley. The Stranding of the White Rose. 2s. $6 \mathrm{~d}$. The Queen of the Extinct Volcano. 2s. 6d.

Le Feuvre, Amy. Granny's Fairyland. 1s.

McGregor, R. J. The Secret Jungle. 2s. (A story of India.)

Maclure, Captain K. Colin of the Seven Seas. 2s. 6d. (A thrilling and well-written chronicle of modern life at sea.)

The Liberators. 2s. 6d. (Stirring adventures overseas.)

Marchant, Bessie. Athabasca Bill. A Tale of the Far West. 2s. 6d. The Deputy Boss. A Tale of British Honduras. 2s.

The House at Brambling Minster. 2s. 6d. (An amusing tale of a haunted house.)

A Brave Little Cousin. 3s.

Darling of Sandy Point. 2s, 6d. (A boy's adventures around the shores of the Straits of Magellan.)

The Mysterious City. 2s. 6d. (A story of the Congo.)

Redwood Ranch. 3s. (Adventures of a boy lost in a Californian forest.)

Rolf the Rebel. 2s. 6d. (Exciting adventures in Cuba.)

The Western Scout. 2s. 6d.

Martin, E. Le Breton. The Mystery Scout. 2s. $6 \mathrm{~d}$. 
Marx, W. James. The Gold Hunters. 3s. (A story of the Californian goldfields.)

Merivale, Joy. Jumped by Convicts. A Tale of Plantation Life in British Guiana. 2s. $6 \mathrm{~d}$.

Miles, Edith. The Girl Chums of Norland Road. 2s.

Mills, Theodora. Princess Lily of the Valley. 2s.

Two from Town. 2s. (Two charming stories for children.)

Moore, Dorothea. A Nest of Malignants. A Story of the Civil War. 2s.

In the Reign of the Red Cap. A Story of the French Revolution. 1s. 3d.

My Lady Venturesome. 1s. 6d. (A story of the Monmouth invasion.)

Adventurers Two. A Story of the Vendean Rising. 2s. 6d. (Relates the adventures of an English boy and girl during the French Revolution.)

Mort, Anne. The Silver Fish. 1s.

Red Rabbit. 1s. 3d.

Red Rabbit's Family. 1s. 6d.

Nackington, $\mathbf{M}$. With Bligh of the Bounty ; or, From Tofoa to Timor. 1s. 6d. (The famous story of the Mutiny of the Bounty.)

Nash, F. O. H. How Audrey became a Guide. 18.

Audrey in Camp. 1s.

Dick's Hero. 1s.

Audrey at School. 1s. 3d.

Rosie the Peddler. 1s. 6 d.

Some Brownies and a Boggart. 1s.

Richenda and the Mystery Girl. 2s.

Nicholson, Mrs. R. T. The Tudor Necklace. 23. 6d. (A very original historical story.)

Owsley, Sibyl B. The School they Handed On. 3s.

Eardley House. A Tale of School Life. 3s.

Skimpy and the Saint. 2s.

Oxenham, Elsie J. Finding Her Family. A Story for Girls. 2s. 6d.

Palgrave, M. E. Under the Blue Flag. A Story of Monmouth's Rebellion. 2s. $6 \mathrm{~d}$.

Pares, Winifred. Hen and Chickens. 2s. (A story of girl life in the Great War.)

Poor Man's Pepper. 1s. 6d.

Four Winds. 1s. 6d. (A charming home tale for children.)

The Creaking Bough. 1s. 6 d.

Through the Nursery Gate. 1s. 3d.

The Ivory Picture. 1s. 
Penny, Alfred. The Headhunters of Christabel. A Tale of Adventure in the Sonth Seas. 3s. 6d.

Peppard, Tess. Seven Robins. 1s. 3d.

Phillimore, Catherine Mary. The King's Namesake. A Tale of Carisbrooke Castle. 2s. 6d.

Plunket, Ierne L. The Hidden Chalice. 3s. (A tale of the dissolution of the monasteries.)

Quiller-Couch, Mabel. The Making of Mona. 2s. 6d.

Ramsey, L. F. An Island for Two. 2s. 6d. (A school story.)

Richardson, A. Eva. The Moon Lady. A Story for Children. 1s. 3d.

Roding, M. Tweedledum and Tweedledee. A Story for Children. 1 s. $3 \mathrm{~d}$.

Rudolf, Robert de Mountjoie. A Year of Adventure. 2s. 6d.

The Wiltons in War Time. 2s.

Sylvia Finds a Fairy. 2s. (A delightful and original phantasy.)

The Treasure League. 2 s. $6 \mathrm{~d}$.

Sadler, S. W., R.N. Adventures of Marshall Vavasour, Midshipman. 2s.

Scarlett, Peter. Bickering with the Dons. A Tale of Bristol Privateers. 2s.

Sherlock, A. B. The Sea Raiders. 2s. 6 d.

Galleon Treasure. 2s. 6d. (Adventures on sea and land described with Jules Verne-like imagination.)

Smith, D. M. Percy. The Lamb House Plot. 2s.

The Perilous Album. 1s. 3d.

The Vicarage Twins. 1s.

Southon, Arthur E. A Yellow Napoleon. A Romance of West Africa. 2s. $6 \mathrm{~d}$.

Jackson's Ju-Ju. 2s. 6 d.

The Laughing Ghosts. Tales of Adventure in West Africa. 6s.

Drums of Fate. A Romance of West Africa. 7s. $6 \mathrm{~d}$.

(Mr. Southon reproduces the atmosphere of the West African bush with uncanny skill.)

Stables, Gordon, M.D., C.M., R.N. From Greenland's Icy Mountains. 2s. 6d. (A tale of the Polar Seas.) 
Talbot, Ethel. Fellow Fags. 1s. 6 d.

The Mystery of the Manor. 1s.

Holiday Chums. 1s. 3d.

The Family Next Door. 1s. 3d.

The Island Camp. 1s.

The Stranger in the Train. 1s. $3 \mathrm{~d}$.

While Mother was Away. 1s.

Tiddeman, L. E. Ray and Fairy. 1s. 6 d.

The Bottle of Sweets. 1s.

Molly's Decision. 3s.

Nancy and Her Cousins. 2s.

Next Door Gwennie. 2s.

When Bab was Young. 2s.

Tyrrell, Mabel L. The Beggar Princess. 3s.

Underdown, Emily. Mick, an Ugly Dog. $1 \mathrm{~s}$.

Vernon, Amy Cripps. Derek's Hero. 2s. 6d.

Colin and Joan. $1 \mathrm{s.}$

Waithman, Lilla. Lenny from London. 1s. $3 \mathrm{~d}$.

Wallace, Dillon, With Dog and Canoe. 3s. 6d. (A story of the icy North, pouring out adventures at every turn.)

Way, Arthur S., D.Litt. Sons of the Violet Crowned. A Tale of Ancient Athens. 4s. 6 d.

Whitehead, Kate. The King's Legacy A Story of the French Revolution. 2s. $6 \mathrm{~d}$.

Whiting, Mary Bradford. The Fortunes of Eglantine. 2s. 6d. (A book for girls.)

The Moulding of Marjorie. 2s.

Williams, E. W. (Editor). The Baymen of Belize, and How They Rescued British Honduras from the Spaniards. Told by one of them-Steven Forbes. 2s. $6 \mathrm{~d}$. 


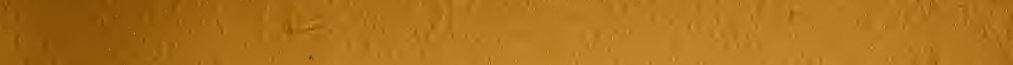
to

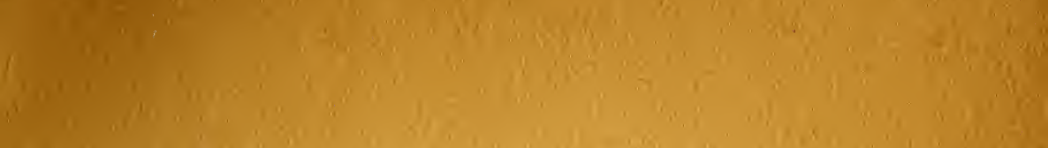
15. 10
4 $\operatorname{lin}_{1}+1$ $\operatorname{lin}_{1}=12 x$

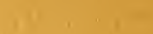

\section{Y il}<smiles>CC(C)C</smiles>

1
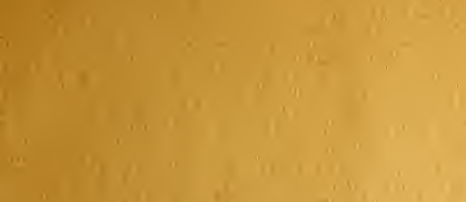

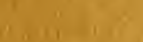

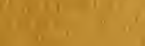




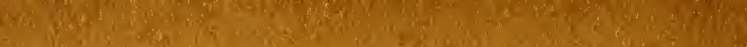

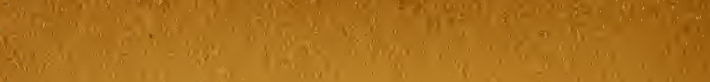

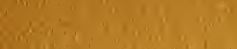

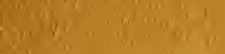

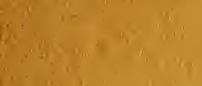

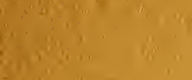

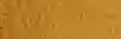

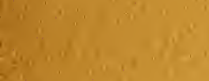

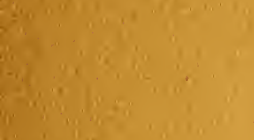

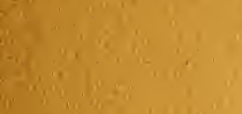

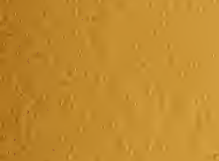

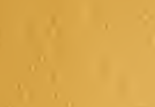

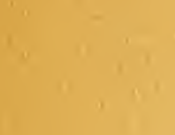

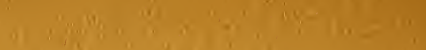

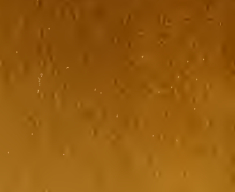
$+4 y^{\prime}$

.

(i) 26

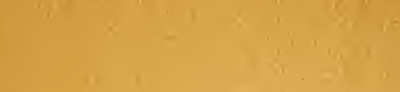

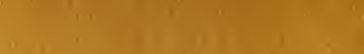

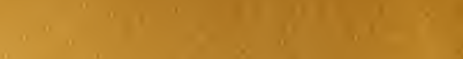

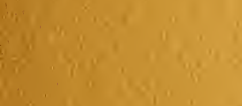

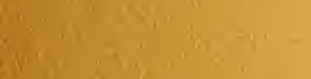
$\lim _{x \rightarrow 1}$

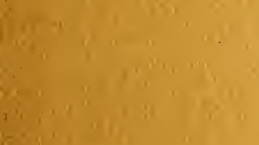

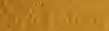

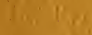

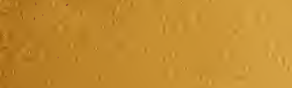

We.

a.

is

$\lim ^{0} y^{2}$

W.

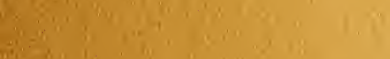

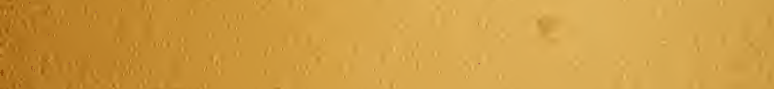

it.

,

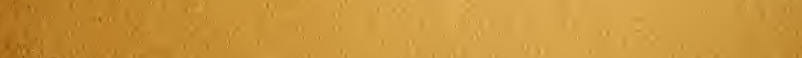

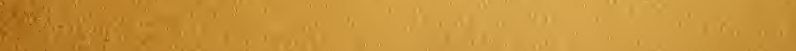

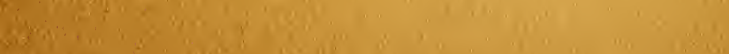




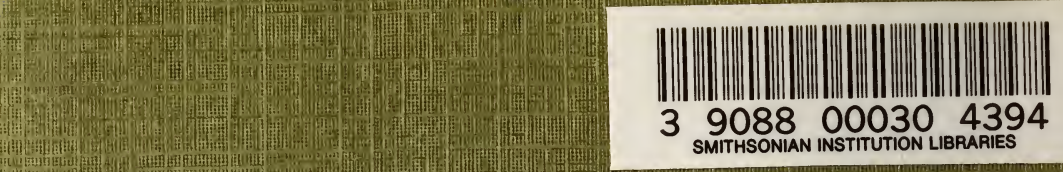

